\title{
Background Data and Statistics on Low- Income Energy Use and Burden for the Weatherization Assistance Program: Update for Fiscal Year 2020
}

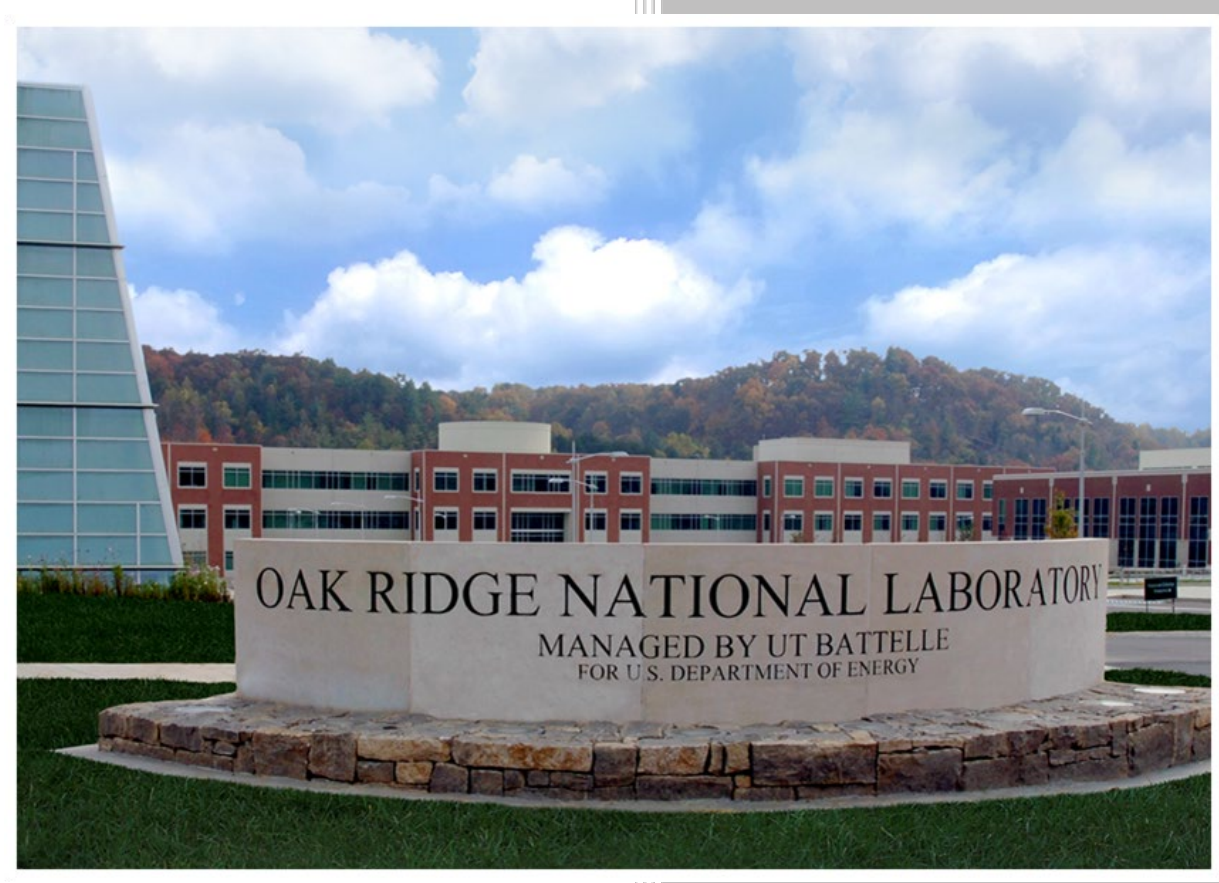

Erin Rose

Beth Hawkins

June 2020 


\title{
DOCUMENT AVAILABILITY
}

Reports produced after January 1, 1996, are generally available free via US Department of Energy (DOE) SciTech Connect.

Website www.osti.gov

Reports produced before January 1, 1996, may be purchased by members of the public from the following source:

\author{
National Technical Information Service \\ 5285 Port Royal Road \\ Springfield, VA 22161 \\ Telephone 703-605-6000 (1-800-553-6847) \\ TDD 703-487-4639 \\ Fax 703-605-6900 \\ E-mail info@ntis.gov \\ Website http://classic.ntis.gov/
}

Reports are available to DOE employees, DOE contractors, Energy Technology Data Exchange representatives, and International Nuclear Information System representatives from the following source:

Office of Scientific and Technical Information

PO Box 62

Oak Ridge, TN 37831

Telephone 865-576-8401

Fax 865-576-5728

E-mail reports@osti.gov

Website http://www.osti.gov/contact.html

This report was prepared as an account of work sponsored by an
agency of the United States Government. Neither the United States
Government nor any agency thereof, nor any of their employees, makes
any warranty, express or implied, or assumes any legal liability or
responsibility for the accuracy, completeness, or usefulness of any
information, apparatus, product, or process disclosed, or represents that
its use would not infringe privately owned rights. Reference herein to
any specific commercial product, process, or service by trade name,
trademark, manufacturer, or otherwise, does not necessarily constitute
or imply its endorsement, recommendation, or favoring by the United
States Government or any agency thereof. The views and opinions of
authors expressed herein do not necessarily state or reflect those of the
United States Government or any agency thereof. 
Energy and Transportation Science Division

BACKGROUND DATA AND STATISTICS ON LOW-INCOME ENERGY USE AND BURDEN FOR THE WEATHERIZATION ASSISTANCE PROGRAM: UPDATE FOR FISCAL YEAR 2020

\author{
Erin Rose \\ Beth Hawkins
}

June 2020

Prepared by

OAK RIDGE NATIONAL LABORATORY

Oak Ridge, TN 37831-6283

managed by

UT-BATTELLE, LLC

for the

US DEPARTMENT OF ENERGY

under contract DE-AC05-00OR22725 


\section{CONTENTS}

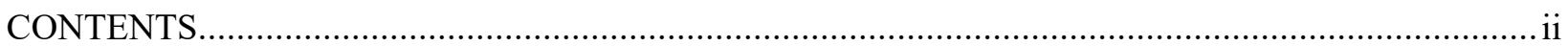

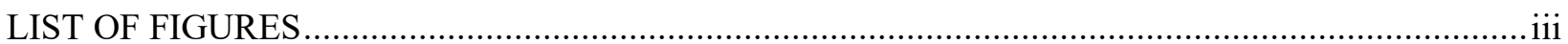

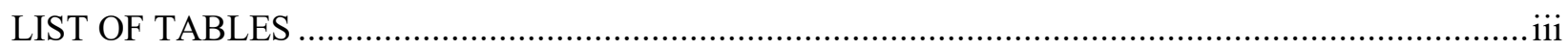

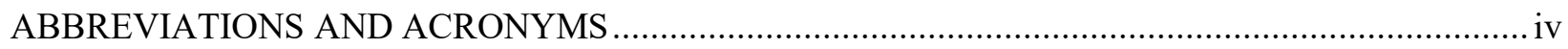

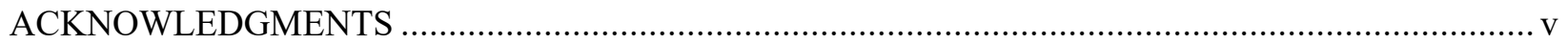

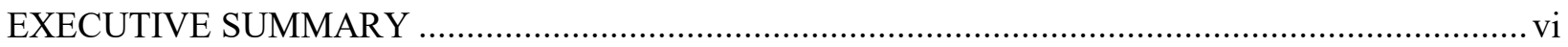

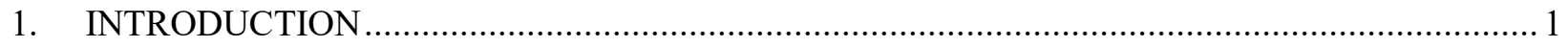

2. ENERGY-RELATED CHARACTERISTICS OF LOW-INCOME HOUSEHOLDS...................... 3

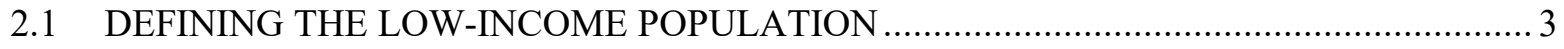

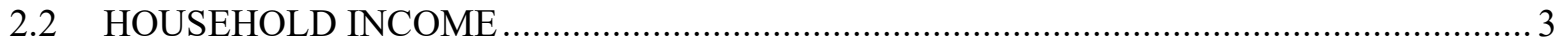

2.3 HOUSING AND HOUSEHOLD CHARACTERISTICS …...................................... 4

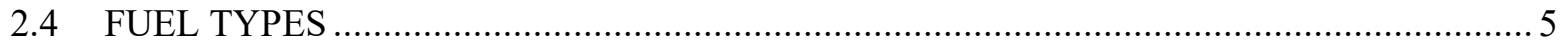

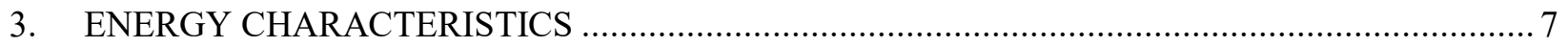

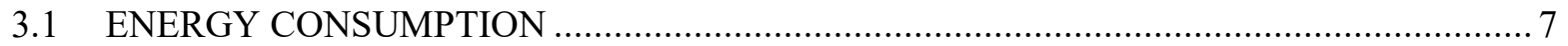

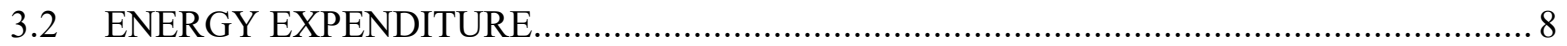

3.3 DISTRIBUTION OF WAP-ELIGIBLE HOUSEHOLD ENERGY EXPENDITURES .......... 10

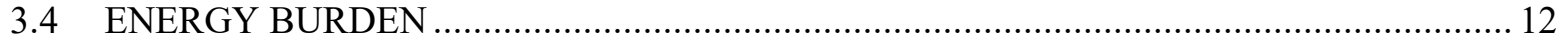

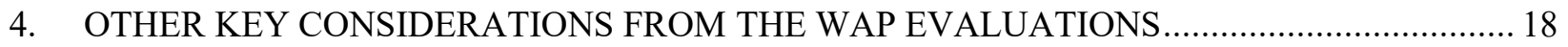

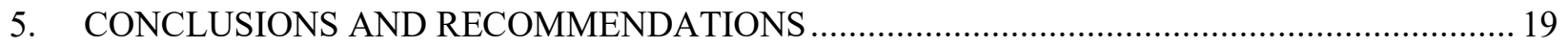

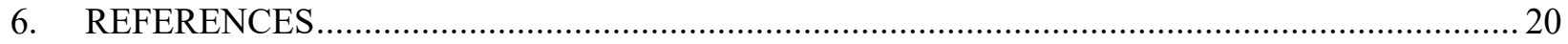

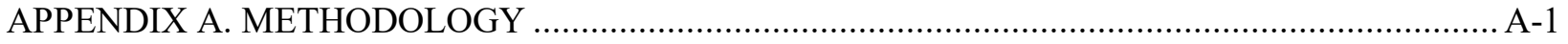




\section{LIST OF FIGURES}

Figure 1. Comparison of housing type between WAP national evaluation and 2009 RECS.................... 4

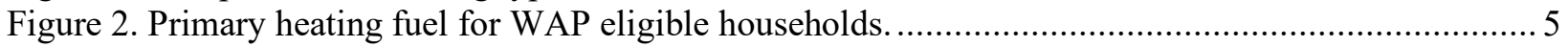

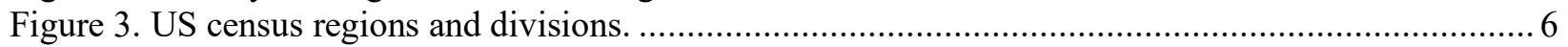

Figure 4. Comparison of fuel type between WAP national evaluation and 2009 RECS......................... 6

Figure 5. Estimated energy expenditures for FY 2020 by primary heating fuel.................................. 8

Figure 6. Primary heating fuel for FY 2020 by housing type. ................................................... 9

Figure 7. Estimated energy expenditures for FY 2020 by housing type............................................. 9

Figure 8. Expected energy expenditures for FY 2020 by census region for the WAP-eligible

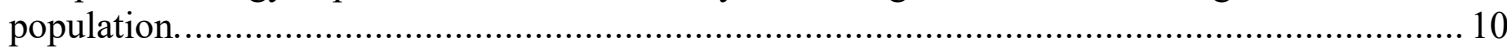

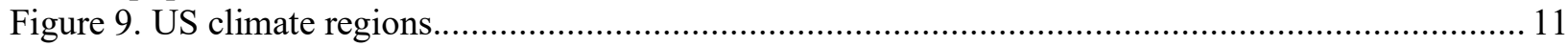

Figure 10. Expected energy expenditures for FY 2020 by climate region for the WAP-eligible

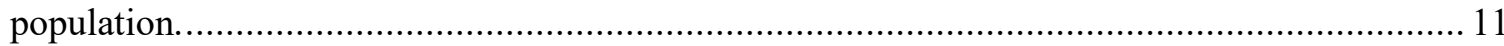

Figure 11. Distribution of annual energy expenditures for the WAP-eligible population....................... 12

Figure 12. Mean energy burden by poverty status. .................................................................... 13

Figure 13. Distribution of annual energy expenditures for the WAP-eligible population........................ 13

Figure 14. Energy burden for FY 2020 by poverty status. ......................................................... 14

Figure 15. Energy burden for FY 2020 by census region. ............................................................ 15

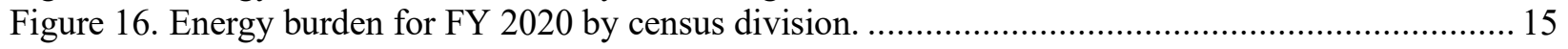

Figure 17. Mean energy burden for FY 2020 by climate region................................................... 16

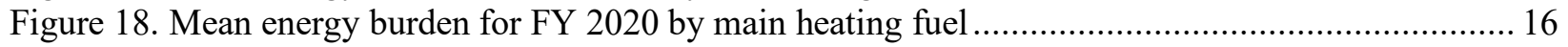

Figure 19. Mean energy burden for FY 2020 by housing type.................................................... 17

\section{LIST OF TABLES}

Table 1. Occupant survey findings: reduced energy burden after weatherization ............................... 18 


\section{ABBREVIATIONS AND ACRONYMS}

$\begin{array}{ll}\text { BLS } & \text { US Bureau of Labor Statistics } \\ \text { CFR } & \text { Code of Federal Regulations } \\ \text { CPI } & \text { Consumer Price Index } \\ \text { DOE } & \text { US Department of Energy } \\ \text { EERE } & \text { Office of Energy Efficiency and Renewable Energy } \\ \text { EIA } & \text { Energy Information Administration } \\ \text { FY } & \text { fiscal year } \\ \text { HUD } & \text { US Department of Housing and Urban Development } \\ \text { LPG } & \text { liquefied petroleum gas } \\ \text { MBtu } & \text { thousand British thermal units } \\ \text { MMBtu } & \text { million British thermal units } \\ \text { ORNL } & \text { Oak Ridge National Laboratory } \\ \text { PY } & \text { program year } \\ \text { RECS } & \text { Residential Energy Consumption Survey } \\ \text { SPSS } & \text { Statistical Package for the Social Sciences } \\ \text { STEO } & \text { Short-Term Energy Outlook } \\ \text { WAP } & \text { Weatherization Assistance Program } \\ \text { WIC } & \text { Women, Infants, and Children } \\ \text { WIPO } & \text { Weatherization and Intergovernmental Programs Office }\end{array}$




\section{ACKNOWLEDGMENTS}

This research was supported by the US Department of Energy (DOE) Office of Energy Efficiency and Renewable Energy (EERE) Weatherization and Intergovernmental Programs Office (WIPO). The authors would like to thank the many people who contributed their time to the review of this report, including Mark Ternes with Oak Ridge National Laboratory (ORNL), Derek Schroeder with DOE WIPO, and Bruce Tonn with Three ${ }^{3}$, Inc. The authors would also like to acknowledge the original author, Joel Eisenberg, whose work was adapted for this project. 


\section{EXECUTIVE SUMMARY}

This report provides updated estimates of the energy consumptions, energy expenditures, and energy burdens of the population eligible to be served through the US Department of Energy (DOE)

Weatherization Assistance Program (WAP) and by proxy, those clients actually served by the program. WAP provides weatherization services to income-eligible households and is the largest single national residential energy efficiency program operating within the United States. Estimating these energy characteristics for the WAP-eligible population helps to establish the need for WAP and provides data on the program's effectiveness in meeting its statutory mandate to reduce total residential energy expenditures while prioritizing assistance to targeted households, including high-residential energy users and households with high energy burdens. ${ }^{1}$ These estimates also help to characterize the WAP-eligible population's energy burden, and they provide insight into the potential for reductions in burden as a result of energy savings achieved through WAP.

This report updates the analyses previously performed by Eisenberg $(2010,2014)$ and provides further reasonable, transparent estimates of energy usage, expenditures, and burden across the WAP-eligible population. These estimates, especially those for energy burden, are stratified by household characteristics (i.e., poverty status, housing type, equipment, and fuel types), climate region, and geographic location. For the purposes of this analysis, WAP-eligible households are identified as those living at or below $200 \%$ of US federal poverty guidelines ${ }^{2}$ based on household income and size. The term energy burden is defined herein as the percentage of household income spent on home energy expenditures (e.g., heating and cooling, appliances, lighting).

Eisenberg's approach integrates two products from the DOE Energy Information Administration (EIA): the Residential Energy Consumption Survey (RECS) ${ }^{3}$ for 2009 and the Short-Term Energy Outlook (STEO) for October or November from various years. RECS is an occasional survey of US households dating back to 1978 that provides detailed data on self-reported housing and energy characteristics, selfreported demographics, and energy consumption and expenditures verified through billing data. Although the 2015 RECS is the most recent completed data collection, the 2015 RECS was not used to generate estimates of energy characteristics for FY 2020 because households could not be grouped by poverty status using the 2015 RECS. The 2015 RECS used wider income bands compared to the narrower income bands used in the 2009 RECS. ${ }^{4}$ Without being able to determine which households would qualify for WAP, the 2015 RECS was not useable for this effort. The 2009 RECS was deemed to supply the most useful data for identifying WAP income-eligible households and to provide more extensive, more robust energy consumption and billing data. The 2009 RECS database includes records on 12,083 individual households. The second EIA data resource used is the STEO monthly estimate of projected energy prices for the 18-month period immediately ahead, beyond October or November of a given year.

To produce estimates of energy expenditures and burdens for the WAP-eligible population for fiscal year (FY) 2020 (October 2019 through September 2020), analysts used Eisenberg's model (2010, 2014; Appendix A) that first normalized energy consumptions based on collected billing data (2009 RECS) to typical weather conditions using heating and cooling degree days. To account for important changes since the 2009 RECS was administered, modifications were made to adjust energy expenditures for changes in fuel costs, and multipliers were added to adjust for increases in income between 2009 and 2020. Fuel

\footnotetext{
${ }^{1}$ Under the authority of Title 42 of the US Code, Chapter 81, Subchapter III, Part A, 6861; Code of Federal Regulation 10 CFR Part 440; 65 FR 77217, Dec. 8, 2000, as amended at 71 FR 35778, June 22, 2006.

22019 Poverty Guidelines US States; Retrieved from the US Department of Health and Human Services; https://aspe.hhs.gov/poverty-guidelines.

${ }^{3}$ US EIA RECS; Retrieved from https://www.eia.gov/consumption/residential/data/2009/

${ }^{4}$ It is anticipated that the 2020 RECS administered by EIA will revert to narrow income bands, allowing for better classification of household poverty status necessary for identifying WAP-eligible households.
} 
price adjustments were made to Eisenberg's model using STEO fuel price projections published in October 2019 for the upcoming 12 months (i.e., FY 2020).

The mean income of the WAP-eligible population for FY 2020 using the adjusted 2009 RECS dataset was estimated to be $\$ 22,243$, with home energy costs estimated to be $\$ 1,782$ annually. The mean energy burden for the WAP-eligible population across the United States for FY 2020 is estimated to be 13.9\% compared to $3.0 \%$ for households living above the $200 \%$ poverty threshold. ${ }^{5}$ The mean energy burden for households living below the $100 \%$ federal poverty line was estimated to be $30.9 \%$. When stratified by fuel type, WAP-eligible households heating with fuel oil experience the highest energy burden at $22.0 \%$. Households living in the mixed-humid climate zone also experience a high energy burden at $16.7 \%$. The lowest energy burdens for WAP-eligible households are found in the West Census region of the United States and in the hot-dry / mixed-dry climate region, which both have an energy burden of $8.5 \%$. The Marine climate zone, which is also in the West region of the United States, has an energy burden of 9.5\%.

WAP's most recent national evaluations collected and generated data pertinent to clients actually served by WAP in 2008 and 2010. Select findings from the national WAP evaluations are included in this report to complement the analyses of the 2009 RECS data and to allow energy characteristics to be compared between the general population eligible for WAP as surveyed through the 2009 RECS and WAP program recipients (i.e., to the population actually served by WAP).

Conclusions derived from this study are that

- WAP continues to serve a population with an energy burden that is much greater than the rest of the county.

- The energy burden for the WAP-eligible population has remained steady at this high level over the last decade. The energy burden for the WAP-eligible population for FY 2010 and FY 2014 was previously estimated to be $14.2 \%$ and $16.3 \%$, respectively.

- The energy burden estimated for the WAP-eligible population should be representative of households weatherized by WAP.

- WAP clients with energy burdens that are higher than average could be targeted by focusing on eligible households or houses with select characteristics.

It is recommended that the analysis presented in this report be updated in FY 2021 when the 2020 RECS data become available. The 2020 RECS will provide current utility bills and incomes for the WAPeligible population that will not require significant if any adjustments as required in using the 2010 RECS for this analysis.

It is also recommended that energy burdens calculated for the WAP-eligible population from this or future analyses be compared to energy burden data for clients actually served by the program if and when such data are collected and become available. Such analysis will help identify differences between the WAP-eligible population and the population actually served by the program and if changes are desired in how clients are selected or marketed.

\footnotetext{
${ }^{5}$ Mean income, home energy costs, and energy burdens were calculated using a 5\% trimmed mean. A trimmed mean is a method of averaging that excludes extreme values on the low and high ends of the sample distributions. It is less sensitive to outliers or data points on the tails of a distribution that may unfairly affect the traditional mean.
} 


\section{INTRODUCTION}

The US Department of Energy (DOE) Weatherization Assistance Program (WAP) is the largest single national residential energy efficiency program operating within the United States. It was created by Congress in 1976 under Title IV of the Energy Conservation and Production Act. The purpose and scope of the program as currently stated in US Code of Federal Regulations (CFR) 10 CFR 440.1 is to:

...increase the energy efficiency of dwellings owned or occupied by low-income persons

[...], reduce their total residential expenditures, and improve their health and safety, especially low-income persons who are particularly vulnerable such as the elderly, persons with disabilities, families with children, high residential energy users, and households with high energy burden. ${ }^{6}$

Estimating the energy consumptions, energy expenditures, and energy burdens of the eligible population served through WAP and for the clients actually served by the program helps to characterize the eligible population and those being served, measure the need for the program, and establish the program's effectiveness in meeting its statuary mandate to reduce expenditures while prioritizing assistance to households with high energy consumptions and high energy burdens. Understanding these characteristics also provides insight into the potential for energy burden reduction through energy savings as a result of WAP.

The term energy burden is defined herein as the percentage of household income spent on home energy expenditures (e.g., heating and cooling, appliances, lighting) and thus is a simple function of household income and energy expenditures. Energy expenditures, income, and energy burden are all responsive to a number of external forces, such as changes in economies ranging from national to local, fluctuations in fuel prices, and impacts of technological and energy efficiency improvements.

This report provides estimates of these energy characteristics (i.e., energy consumption, energy expenditure, and energy burden) for Fiscal Year (FY) 2020 for households that are income-eligible to receive services through WAP, and by proxy, those clients who are actually served by the program. In so doing, this report updates estimates developed for FY 2010 and FY 2014 by Joel Eisenberg $(2010$, 2014). Until data resources are available to directly measure these energy characteristics for the households served by WAP, they must be estimated using external data sources representing the general eligible population.

The analysis presented in this report is based on data provided in the Energy Information Administration (EIA) Residential Energy Consumption Survey (RECS) of 2009. RECS provides detailed data on housing characteristics, energy characteristics, and demographics that are self-reported, as well as energy consumption and expenditures verified through billing data. The 2009 RECS used for this analysis is not the most recent survey in this series. Although the 2015 RECS is the most recent completed data collection, the 2015 RECS was not used to generate estimates of energy characteristics for FY 2020 because households could not be grouped by poverty status using the 2015 RECS. The 2015 RECS used wider income bands compared to the narrower income bands used in the 2009 RECS. ${ }^{7}$ Without being able to determine which households would qualify for WAP, the 2015 RECS was not useable for this effort. The 2009 RECS was deemed to supply the most useful data for identifying WAP income-eligible

\footnotetext{
${ }^{6}$ See footnote 1.

${ }^{7}$ It is anticipated that the 2020 RECS administered by EIA will revert to narrow income bands, allowing for better classification of household poverty status.
} 
households and to provide more extensive, more robust energy consumption and billing data. The 2009 RECS database contains records on 12,083 individual households.

To produce energy expenditure and burden estimates for the WAP eligible population for FY 2020, the 2009 RECS energy consumption data derived from collected billing data were normalized to typical weather conditions using heating and cooling degree days. Adjustments were made in the 2009 RECS data to account for changes in fuel costs that occurred between 2009 and 2020 using EIA's Short-Term Energy Outlook (STEO) fuel price projections by census region and division in various years. Household income was adjusted for inflation from 2009 to 2020 using the US Bureau of Labor Statistics (BLS) inflation indices by census region.

Section 2 of this report defines the WAP-eligible population and the population served by WAP. Household and housing characteristics are also provided to better understand these populations. Section 3 provides estimates of energy consumption, expenditures, and burden for FY 2020 based on the 2009 RECS subsample eligible for WAP. Energy burden estimates are then presented with consideration to poverty levels, census region and division, climate zones, and heating and cooling costs. Section 4 provides other key findings generated from the most recent WAP evaluations that are useful for understanding the impacts of energy burden on households served through WAP and its potential benefits. Conclusions and recommendations are presented in Section 5. 


\section{ENERGY-RELATED CHARACTERISTICS OF LOW-INCOME HOUSEHOLDS}

Since the 2009 RECS was released, national evaluations have produced and published statistics that directly characterize the clients actually served by WAP for program years (PYs) 2008 and 2010. ${ }^{8}$ Select evaluation findings are used herein to compare statistics for the general WAP income-eligible population found in the 2009 RECS data to the WAP population actually served. Establishing comparisons between the two data sources is important for determining if the RECS population is generally reflective of households served through WAP and can therefore be used, as a proxy, to reflect the energy burden of clients served through WAP.

\subsection{DEFINING THE LOW-INCOME POPULATION}

WAP Grantees (i.e., all 50 US states, the District of Columbia, American Indian Tribes, and the five US territories $^{9}$ ) and Subgrantees (i.e., agencies that deliver WAP to eligible households within established service areas) are required to determine income eligibility for households that apply for services. WAP currently defines eligibility as household income at or below $200 \%$ of the federal poverty guidelines, although WAP Grantees are permitted to use other agreed-upon federal income eligibility guidance to determine eligibility for services. For example, eligibility for many programs at the US Department of Housing and Urban Development (HUD) is defined as household income at or below $80 \%$ of the local area median income.

For the purposes of this analysis, the general approach for determining WAP eligibility (i.e., being at or below $200 \%$ of the poverty guidelines) was used for grouping and classifying participating 2009 RECS households as WAP eligible.

\subsection{HOUSEHOLD INCOME}

The mean income of the WAP-eligible population as provided in the 2009 RECS and adjusted for inflation for FY 2020 is estimated to be $\$ 22,243$ compared to $\$ 83,684$ for households not eligible for WAP. ${ }^{10}$ Overall, the average income for WAP clients served by the program in PY 2010 was less than that estimated for the income-eligible population. Based on household-level information gathered through the national WAP evaluations, WAP households living in single-family homes reported higher annual incomes than households living either in small or large multifamily buildings (i.e., buildings with 2-4 units and 5 or more units, respectively). ${ }^{11}$ The median household income reported by WAP clients residing in single-family homes in PY 2010, adjusted for inflation for FY 2020, is estimated to be $\$ 18,179$ compared to $\$ 12,100$ reported by those living in multifamily buildings. Ten percent of these single-family WAP clients had an income of $\$ 8,387$ or less, and more than $10 \%$ had incomes of $\$ 39,254$ or more (Blasnik et al. 2015; Carroll et al. 2015). ${ }^{12}$

\footnotetext{
${ }^{8}$ The full collection of national WAP evaluation reports can be found at: https://weatherization.ornl.gov/reports/

${ }^{9}$ One important consideration for this analysis is that the 2009 RECS data do not include information for households living in the five United States territories.

${ }^{10}$ Mean incomes were calculated using a 5\% trimmed mean. A trimmed mean is a method of averaging that excludes extreme values on the low and high ends of the sample distribution. It is less sensitive to outliers or data points on the tails of a distribution that may unfairly affect the traditional mean.

${ }^{11}$ Both the 2009 RECS and the WAP national evaluations defined small multifamily buildings as those with 2-4 housing units and large multifamily buildings as those with 5+ housing units. This contrasts with other definitions, such as the definition used by WAP energy audits, which defines small, multifamily buildings to be $2-24$ units and large multifamily buildings to be $25+$ units.

${ }^{12}$ For comparison purposes, WAP recipients' median income reported in PY 2010 has been adjusted using the national BLS Consumer Price Index (CPI) inflation multiplier (1.165) and are presented in 2020 dollars.
} 


\subsection{HOUSING AND HOUSEHOLD CHARACTERISTICS}

Based upon the 2009 RECS, there were approximately 39.5 million households in the United States that were federally eligible for WAP out of 113.6 million households nationwide; within this population, 16.9 million households were categorized as having income at or below the poverty level (Eisenberg 2014).

In his original analyses, Eisenberg $(2010,2014)$ used the 2009 RECS to characterize the WAP-eligible population in terms of household demographics, census region, and housing types. Eisenberg reported that nearly $60 \%$ of households contained at least one paid worker, approximately $28 \%$ received food assistance, $33 \%$ received retirement income, and just under half owned their own homes. The home ownership statistic varies from data gathered through the national evaluations of WAP, which found that $87 \%$ of WAP program recipients were homeowners. Evaluation findings also revealed that only about a third were employed for wages, with an equal percent reporting a retirement status (Carroll et al. 2014a).

According to the 2009 RECS, the WAP-eligible population is generally distributed across the United States in proportions similar to the distribution of the population not eligible for WAP, with approximately $16 \%$ in the Northeast, $23 \%$ in the Midwest, $41 \%$ in the South, and $20 \%$ in the West (Eisenberg 2014). A somewhat higher percentage of households not eligible for WAP, about $4 \%$ more, are in the Northeast, and about 6\% fewer are in the South (Eisenberg 2014).

On balance, housing types did not largely diverge between the WAP-served population (from the national evaluations) and the WAP-eligible population (from RECS data). Figure 1 presents comparisons between WAP units weatherized during PY 2008 (Carroll et al. 2014b) and the WAP-eligible population identified in the 2009 RECS. ${ }^{13}$ More households weatherized in PY 2008 lived in manufactured homes ${ }^{14}$ compared to the WAP-eligible population in 2009 , and fewer households lived in small and large multifamily buildings.

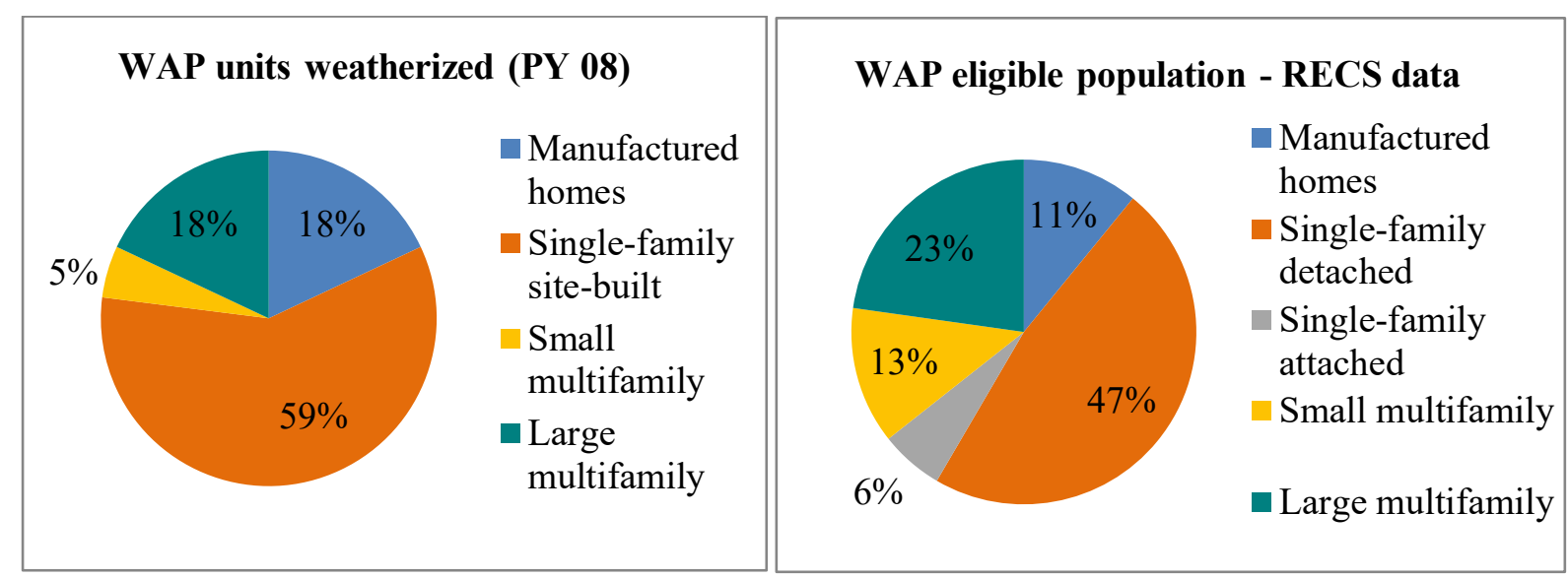

Figure 1. Comparison of housing type between WAP national evaluation and 2009 RECS.

\footnotetext{
${ }^{13}$ In the left chart of Figure 1, "WAP units weatherized," the single-family site-built housing category combines single-family detached and single-family attached housing, which is separated in the 2009 RECS chart.

${ }^{14}$ The term manufactured housing is interchangeable with the term mobile home, which is used in the 2009 RECS for this housing type.
} 


\subsection{FUEL TYPES}

The WAP income-eligible consumers have profiles similar to other consumers in terms of the primary heating fuel type they use, with a slightly higher proportion than the general population using propane ${ }^{15}$ for this purpose (Eisenberg 2014). As shown in Figure 2, the largest single heating fuel type is natural gas, with approximately $43 \%$ of WAP-eligible households using this fuel. Electricity is used as the primary source for heating by $39 \%$ of WAP-eligible households. Home heating oil and propane are used by about $5 \%$ of these households.

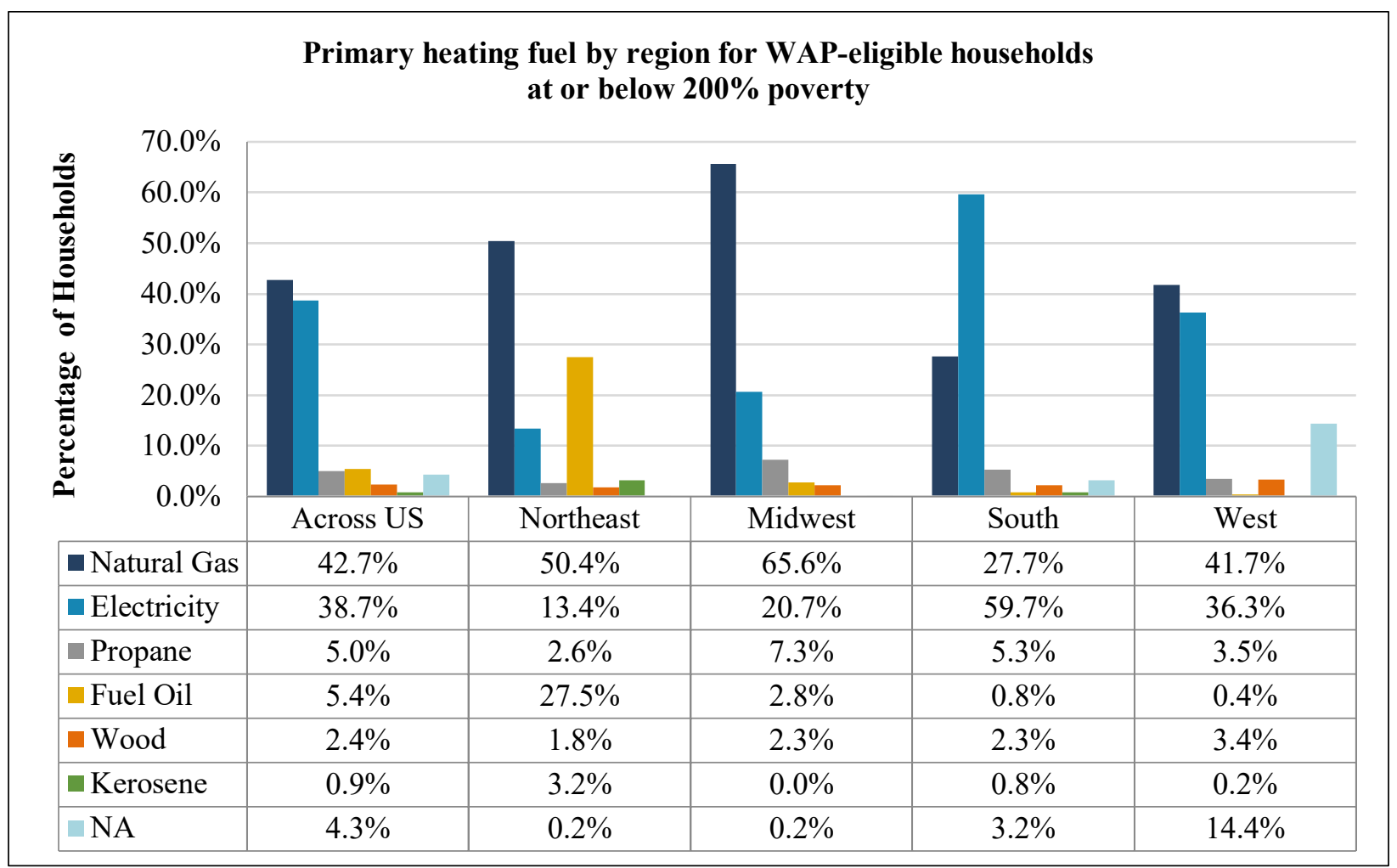

Figure 2. Primary heating fuel for WAP eligible households. ${ }^{16}$

The distribution of heating fuel type varies substantially by census region (Figure 3). Most of the home heating oil is used by WAP-eligible households in the Northeast, whereas electricity is the dominant heating source in the South, and natural gas predominates in the Midwest (Eisenberg 2014). Distribution of heating fuel type has important implications for the average level of residential expenditures and energy burdens in the various parts of the country, as home heating oil and propane prices per thousand British thermal units (MBtu) are higher and often rise more sharply than those of other fuels (Eisenberg 2014). Another key consideration when mapping energy burden across the United States is that residential electricity prices in the Northeast tend to be well above the national average. The overwhelming predominance of natural gas as the primary heating fuel in the Midwest makes WAP-eligible households in that part of the United States extremely sensitive to events in the natural gas markets (Eisenberg 2014).

\footnotetext{
15 The terms propane and liquefied petroleum gas (LPG) are interchangeable.

${ }^{16}$ Source: DOE/EIA Residential Energy Consumption Survey for 2009. Other fuel types (i.e., solar, district steam) accounted for $<1.5 \%$ of the total across the United States and census regions.
} 


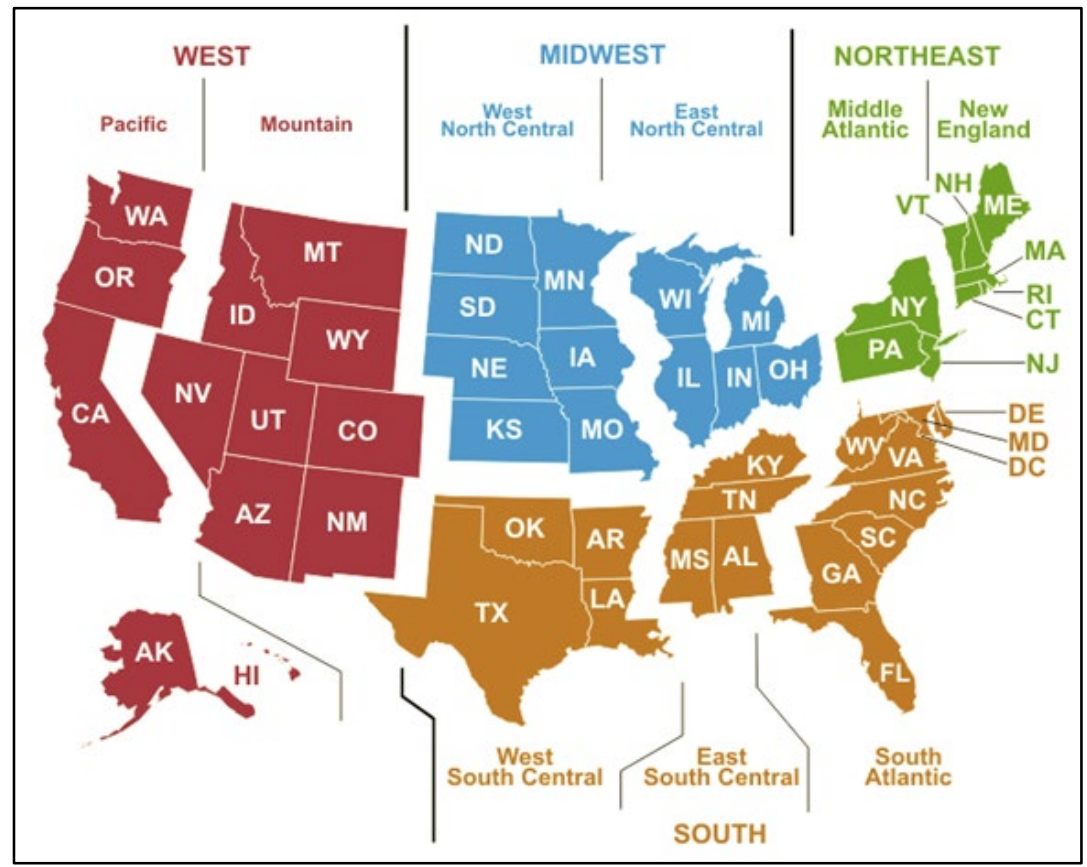

Figure 3. US census regions and divisions. ${ }^{17}$

Figure 4. compares the frequency of primary heating fuel type found between the WAP-eligible population and the WAP-served population ${ }^{18}$ across the United States. Natural gas was the dominant heating source used by both populations, but natural gas was used more frequently in the WAP-served population (58\%) than in the WAP-eligible population (43\%). Conversely, electrically heated homes were less common in the WAP-served population (17\%) than in the WAP-eligible population $(39 \%)$.

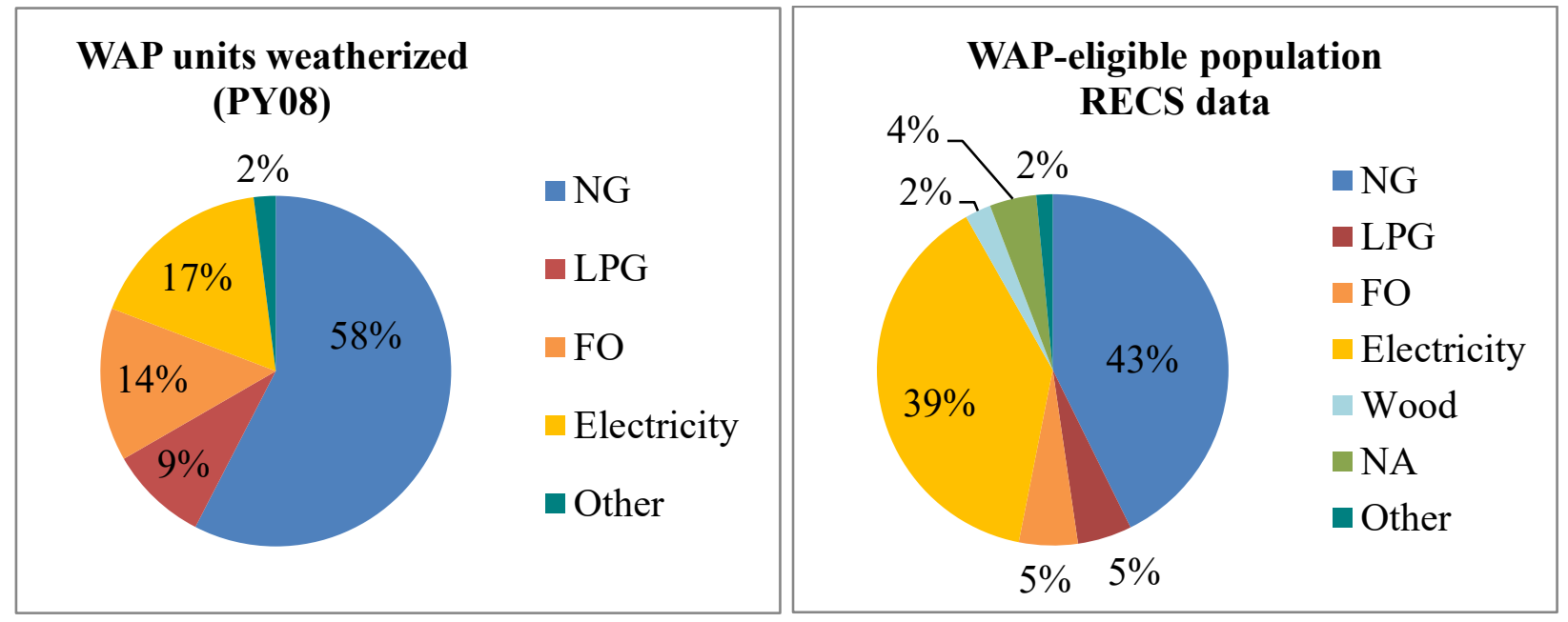

Figure 4. Comparison of fuel type between WAP national evaluation and 2009 RECS.

\footnotetext{
${ }^{17}$ The territories are not shown because, to date, the EIA has not included United States territories (referred collectively in the census as Puerto Rico and the Outlying Areas) in its administration of the RECS.

${ }^{18}$ Statistics for the WAP-served population were generated from Carroll et al. 2014b.
} 


\section{ENERGY CHARACTERISTICS}

Estimates of energy expenditures and energy burden for the FY 2020 WAP-eligible population were produced using data generated by the EIA's 2009 RECS as inputs into the model developed by Joel Eisenberg (2010). As mentioned earlier, the 2015 RECS data did not allow for grouping by poverty status, so these data were not used to generate estimates of energy characteristics for FY 2020. The 2015 RECS provided wider income bands as response categories than the 2009 RECS, so it was not possible to determine which households were within the WAP income-eligible bracket. ${ }^{19}$

Energy consumptions in the 2009 RECS were normalized to standard 30-year historical weather conditions using heating and cooling degree day adjustments. Then, to account for important changes since administering the 2009 RECS, the data were adjusted to account for increases in household incomes due to inflation and changes in fuel costs. Adjustments to fuel costs used integrated data from the EIA's STEO fuel price projections for 2019 and 2020. To adjust for increases in income between 2009 and 2020 due to inflation, multipliers were calculated using the BLS Consumer Price Indices by census region. Appendix A provides detailed information on the methods and sources used to calculate the statistics for this and prior WAP energy burden reports published by Eisenberg $(2010,2014)$.

\subsection{ENERGY CONSUMPTION}

According to the 2009 RECS sample, the average annual weather-normalized energy consumption for households eligible for WAP was 78 million British thermal units (MMBtu) compared to $96 \mathrm{MMBtu}$ for households not eligible for WAP. (Eisenberg 2014). Energy intensity (i.e., Btu consumption for heating and cooling per square foot of conditioned space) showed the reverse pattern (Eisenberg 2014). For eligible households, consumption per square foot averaged $31 \mathrm{MBtu}$, whereas for households not eligible for WAP, the average was $24 \mathrm{MBtu}$ per square foot. This reflects the relative inefficiency of the lowincome housing stock compared to that of other households (Eisenberg 2014). For example, 28\% of WAP-eligible households reported inadequate insulation in their homes, whereas $17 \%$ of households not eligible for- WAP reported this condition (Eisenberg 2014).

A review of the average energy consumption in 2009 for WAP-eligible households by housing type reveals that households living in large multifamily buildings had a lower average annual consumption than those in most other building types, at $46 \mathrm{MMBtu}$ compared to $95 \mathrm{MMBtu}$ for those in single-family detached homes (Eisenberg 2014). It is important to note that average consumption per square foot is higher in the small multifamily housing stock than it is in other building types. The average space conditioning consumption was $46 \mathrm{MBtu}$ per square foot for these homes compared to $29 \mathrm{MBtu}$ per square foot for single-family homes and $37 \mathrm{MBtu}$ per square foot for apartments in large buildings (Eisenberg 2014). This highlights a potential efficiency opportunity in small multifamily buildings. Results from the national WAP evaluation generally align with the 2009 RECS data in that households in large multifamily buildings consume less energy than those in other housing types - close to $30 \%$ less than both singlefamily detached homes and small multifamily buildings (Carroll et al. 2014b).

The RECS data indicate substantial energy efficiency opportunities in the WAP-eligible housing stock in terms of both heating systems and refrigerators if the age of the equipment is used as a rough proxy for inefficiency. Close to $30 \%$ of the refrigerators in WAP-eligible homes in the 2009 RECS were 10 years old or more (Eisenberg 2014). In the 2009 RECS data set, 55\% of the heating systems in these homes were 10 years old or more. A limitation of this analysis is that it is likely that at least some WAP-eligible households would have replaced older, inefficient refrigerators, heating systems, and other equipment and

\footnotetext{
${ }^{19}$ It is anticipated that the 2020 RECS administered by EIA will revert to narrow income bands, allowing for better classification of household poverty status.
} 
appliances since the 2009 RECS was administered, thereby reducing household energy expenditures and energy burden. It is anticipated that updated information on these factors and for the WAP-eligible population will be available after the 2020 RECS is completed.

\subsection{ENERGY EXPENDITURE}

The average annual weather-normalized home energy expenditure for WAP-eligible households estimated for FY 2020 is $\$ 1,782$, of which $\$ 611$ is estimated to be for primary heating and cooling expenses. This compares to estimated average annual energy expenditures of $\$ 2,208$ for households not eligible for WAP, of which $\$ 777$ is estimated for primary heating and cooling. ${ }^{20}$ WAP-eligible households have lower average residential energy usage and lower residential energy bills than households not eligible for WAP. However, as shown in Section 3.3, this difference is not in proportion to household income, resulting in many lower income households experiencing higher energy burden than those not living under poverty thresholds (Eisenberg 2014).

Upon examining home energy costs of WAP-eligible households, several differences are observed across the 2009 RECS sample. Households that use fuel oil and propane as their primary heat sources are expected to have the highest total energy bills for FY2 2020 at $\$ 2,747$ and $\$ 2,649$, respectively (Figure 5). In homes heated by fuel oil and propane, heating and cooling costs are $49 \%$ and $41 \%$ of the total energy expenditure in the house, respectively. This compares to just $32 \%$ in homes heated by electricity.

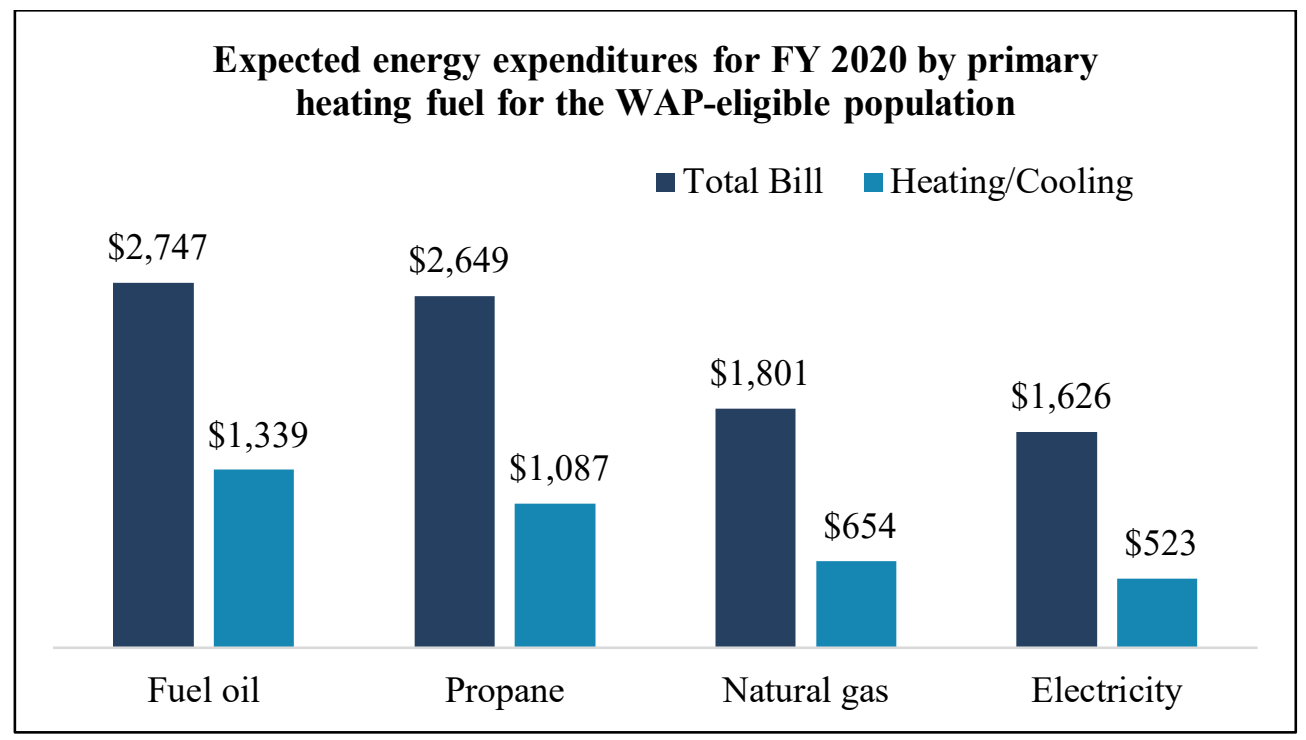

Figure 5. Estimated energy expenditures for FY 2020 by primary heating fuel.

WAP-eligible households in single-family detached homes are expected to have the highest annual home energy expenditures for FY 2020 (\$2,144), primarily heating with natural gas or electricity (Figures 6 and 7). Manufactured homes and single-family attached homes are projected to expend $\$ 1851$ and $\$ 1835$, respectively, with over half of manufactured homes heating with electricity, and single-family attached homes being primarily heated by natural gas or electricity. WAP-eligible households living in large multifamily buildings are expected to have the lowest total energy expenditures across housing types $(\$ 1,160)$, primarily heating with electricity $(51.3 \%)$ or natural gas $(39.5 \%)$.

\footnotetext{
${ }^{20}$ Mean home energy expenditures were calculated using a 5\% trimmed mean. A trimmed mean is a method of averaging that excludes extreme values on the low and high ends of the sample distribution. It is less sensitive to outliers or data points on the tails of a distribution that may unfairly affect the traditional mean.
} 


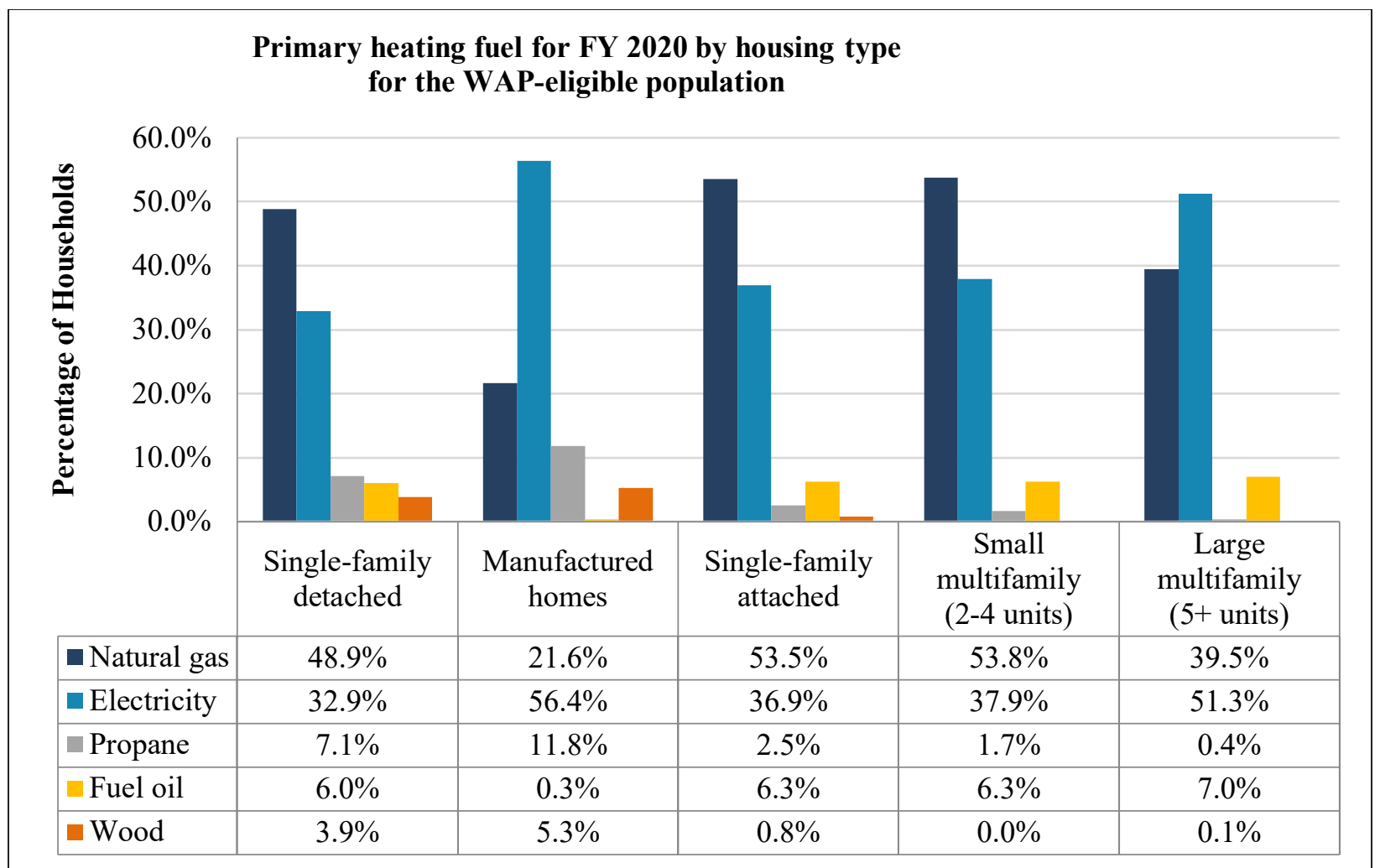

Figure 6. Primary heating fuel for FY 2020 by housing type. ${ }^{21}$

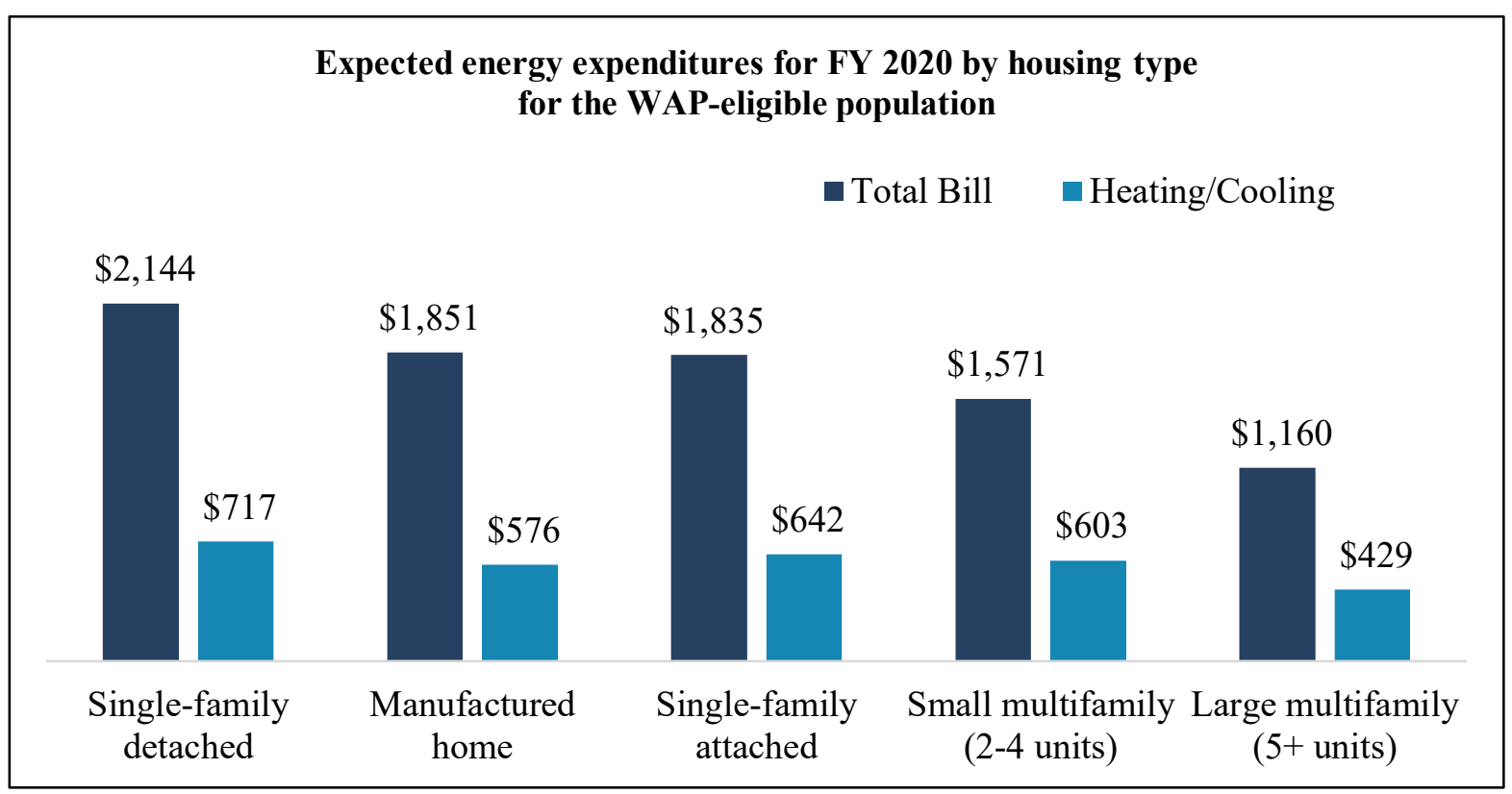

Figure 7. Estimated energy expenditures for FY 2020 by housing type.

\footnotetext{
${ }^{21}$ Source: DOE/EIA Residential Energy Consumption Survey for 2009. Other fuel types (i.e., kerosene, solar, district steam) and non-applicable cases accounted for $<5 \%$ of the total across housing types.
} 
Given the concentration of households in the 2009 RECS WAP sample heating with fuel oil in the Northeast at nearly $28 \%$, it is not surprising that the estimated average total energy expenditure of $\$ 2,089$ for WAP eligible households for FY 2020 is higher there than elsewhere (Figure 8). This compares to $\$ 1,910$ for such households in the Midwest, where less expensive natural gas predominates, and to $\$ 1,757$ for those in the South, where heating loads are lower. WAP-eligible households in the West are projected to have the lowest average annual expenditure of $\$ 1,467$.

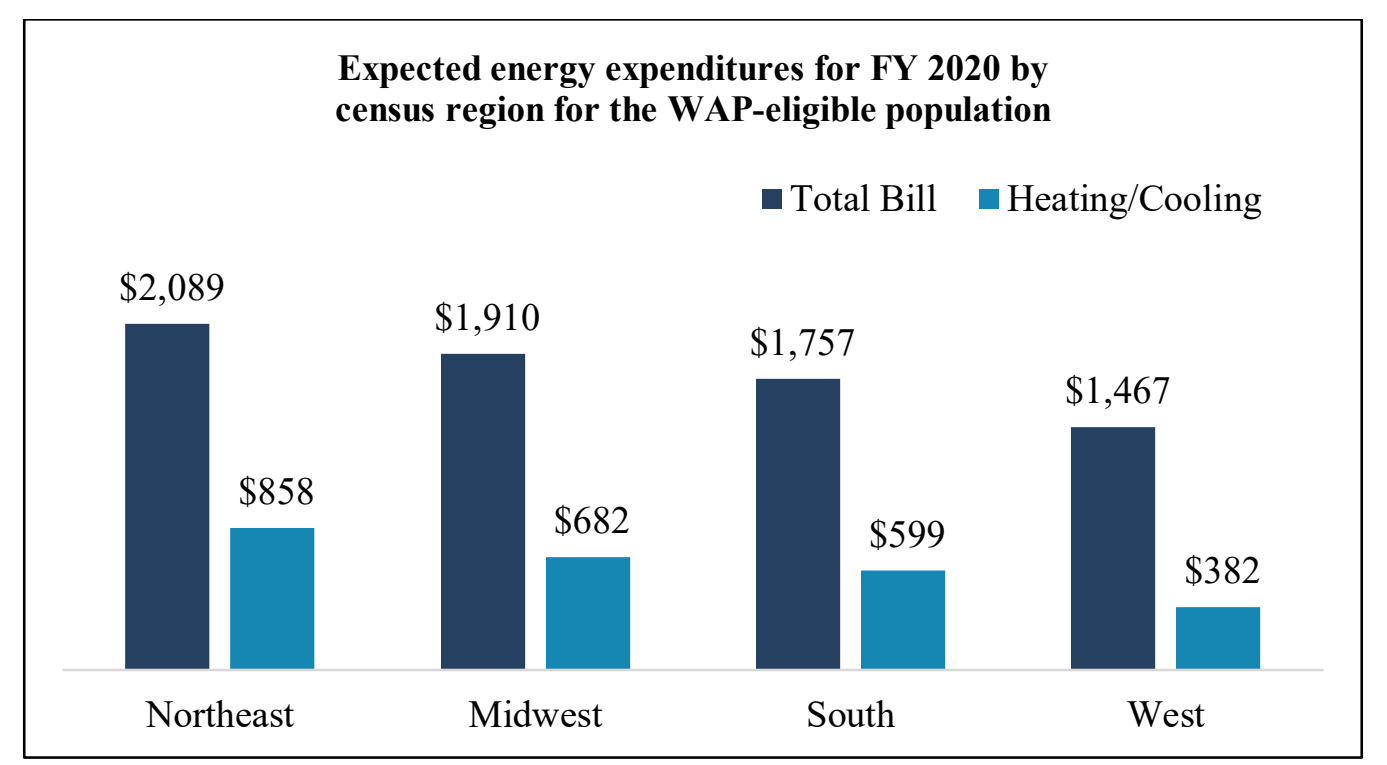

Figure 8. Expected energy expenditures for FY 2020 by census region for the WAP-eligible population.

Home energy expenditures by climate region generally correspond to census regions (Figures 9 and 3, respectively). The highest costs are found in the very cold and cold regions, which include most of the Northeast, Midwest, and West regions, with average costs estimated at $\$ 1,878$ (Figure 10). States in the mixed-humid climate zone, which are generally found in the South region, are expected to have an average energy expenditure of $\$ 1,866$. WAP-eligible households in the hot-dry/mixed-dry and marine climate regions have the lowest estimated home energy costs of $\$ 1,439$ and $\$ 1,413$, respectively, per year. These zones are generally found in the West region.

\subsection{DISTRIBUTION OF WAP-ELIGIBLE HOUSEHOLD ENERGY EXPENDITURES}

The previous discussion highlighted average energy expenditures by fuel and housing type, census region, and climate region. However, household energy expenditures can vary considerably, even among households of similar income levels, those using the same heating fuel, and in similar climates and building types (Eisenberg 2014). Explanatory factors might include variations in building energy efficiency, number of household members, and household behavior, resulting in a wide distribution in energy usage for the 2009 RECS WAP-eligible population, as depicted in Figure $11{ }^{22}$ The bell curve

\footnotetext{
${ }^{22}$ The mean annual energy expenditure for the WAP-eligible population presented in the distribution graph (Figure 11) is $\$ 1,861.73$. This differs from the mean annual energy expenditure of $\$ 1,782$ presented in Section 3.2 because the latter is a $5 \%$ trimmed mean whereas the histogram displays the distribution of all cases.
} 


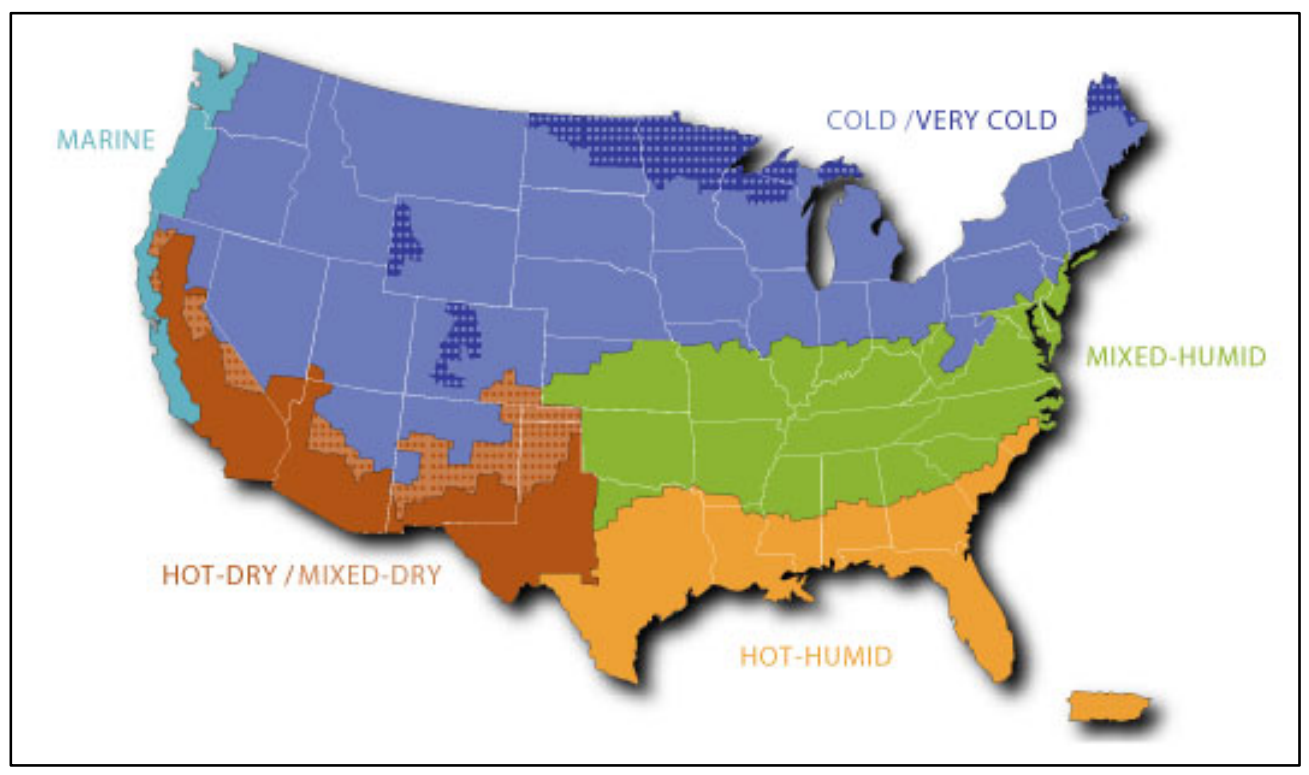

Figure 9. US climate regions. ${ }^{23}$

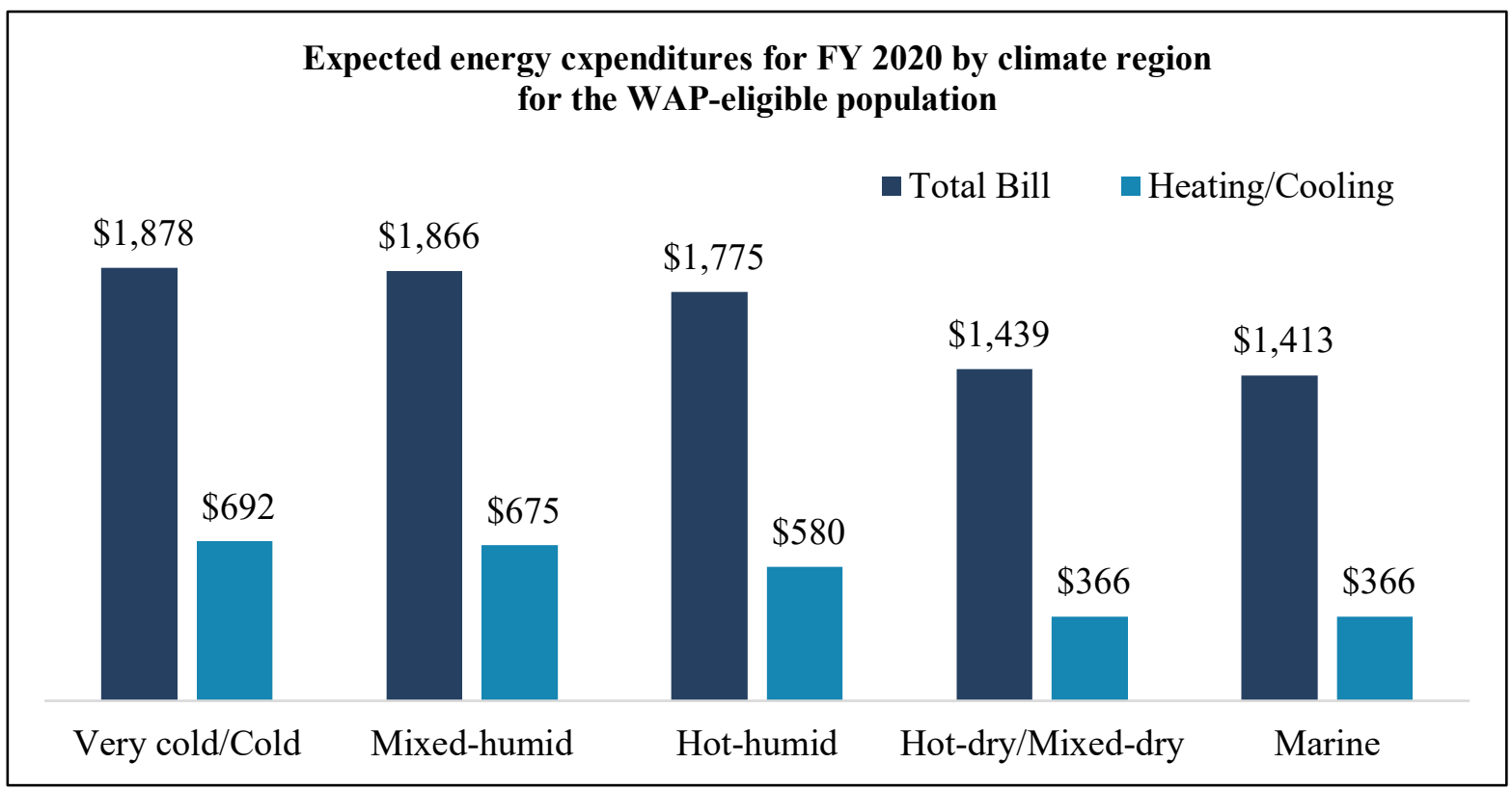

Figure 10. Expected energy expenditures for FY 2020 by climate region for the WAP-eligible population.

23 The 2009 RECS analysis used the "Building America Climate Regions" map for assigning state climate zones. Although Alaska and Hawaii are not included in this map, their climate zones for the 2009 RECS are classified as very cold/cold and hothumid, respectively. The subarctic climate is not included as a region in the 2009 RECS. The climate regions map was retrieved from EIA: https://www.eia.gov/consumption/commercial/maps.php. The 2009 RECS did not include United States territories. 
distribution of energy expenditures with a long tail signals a considerable proportion of WAP-eligible households with energy bills below the average and others with bills that considerably exceed the averages (Eisenberg 2014). The latter would likely be classified as a priority for WAP services as high residential energy users or households with high energy burdens.

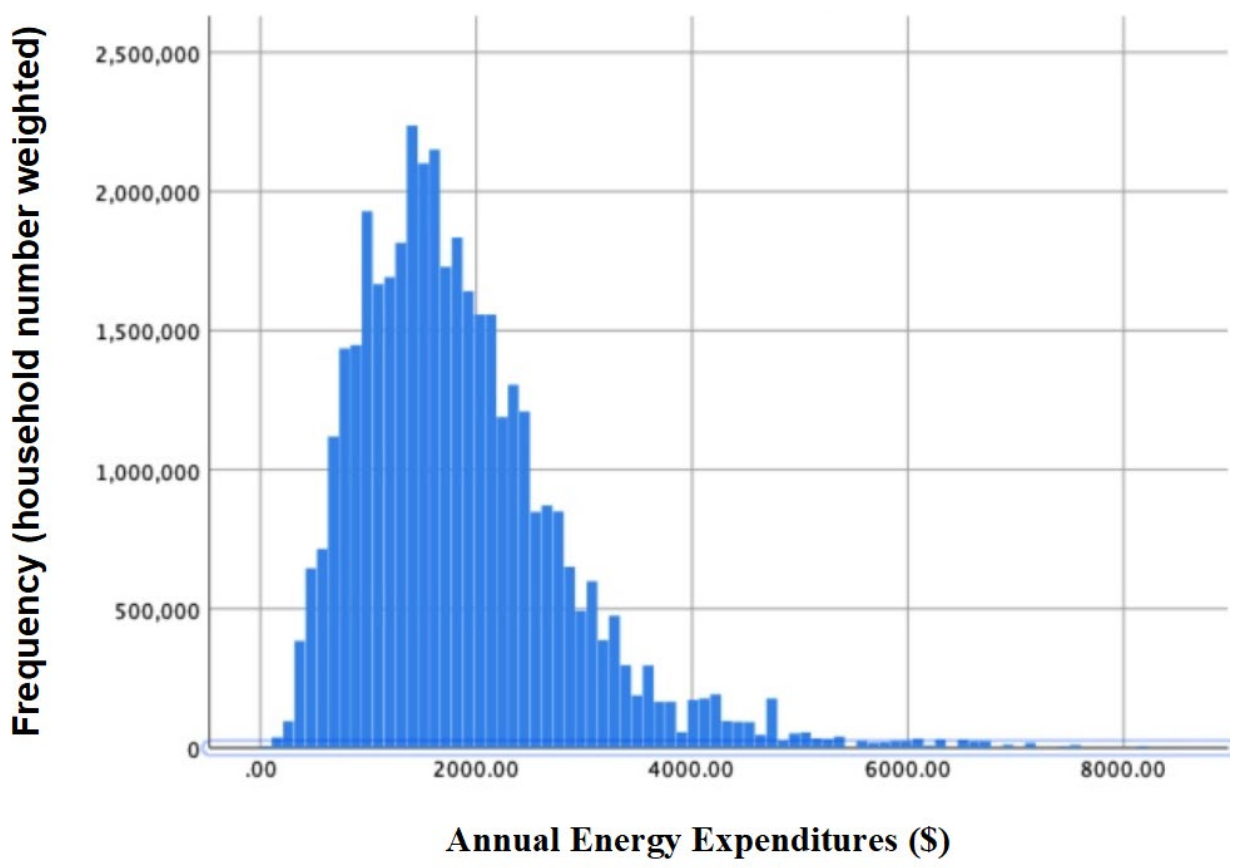

Figure 11. Distribution of annual energy expenditures for the WAP-eligible population. ${ }^{24}$

\subsection{ENERGY BURDEN}

In FY 2020, the energy burden for each household was computed by dividing the home's energy consumption by its household income. ${ }^{25}$ The mean energy burden for the WAP-eligible population was then computed, resulting in an estimated mean energy burden of $13.9 \%$ compared to $3.0 \%$ for noneligible households, as shown in Figure 12. ${ }^{26}$ Energy burden was previously estimated by Eisenberg for FY 2010 and 2014 using the same methodology as this study (Eisenberg 2010, Eisenberg 2014). The energy burden for WAP-eligible households was estimated to be $14.2 \%$ for FY $2010^{27}$ and $16.3 \%$ for FY 2014 compared to $13.9 \%$ for FY 2020. The decrease in energy burden from FY 2014 to FY 2020 is consistent with that observed for the remaining US population (3.5\% in FY 2014 compared to $3.0 \%$ in FY 2020), principally due to falling fuel prices, especially for natural gas.

Similar to the distribution of expected energy expenditures for FY 2020 (Figure 11), the bell curve distribution of energy burden displays a long tail, signaling a large proportion of WAP-eligible

\footnotetext{
24 The frequency in households uses population-weighted data for each census division (see Appendix A).

25 There are two ways that energy burden is generally calculated. Mean Group Burden is computed by calculating the average energy expenditure for all households in a group of interest and dividing by the average income of households in that group. Mean Individual Burden is calculated by dividing each household's energy bill by its income and calculating an average of these individual burdens for the group. Both statistics are valid descriptions of energy burden, with the latter approach generally resulting in a higher calculated value. The latter approach was used in this analysis.

${ }^{26}$ Mean energy burdens were calculated using a 5\% trimmed mean. A trimmed mean is a method of averaging that excludes extreme values on the low and high ends of the sample distribution. It is less sensitive to outliers or data points on the tails of a distribution that may unfairly affect the traditional mean

${ }^{27}$ The definition of WAP-eligible used for FY 2010 was based on Department of Health and Human Services Low Income Home Energy Assistance Program eligibility due to the use of the 2005 RECS.
} 
households with energy burdens below the average and others with burdens that considerably exceed the averages (Figure 13). The majority of WAP-eligible households cluster between 5 and 10\% energy burden. The large number of households between 10 and 20\% and beyond contribute to the mean energy burden of $13.9 \%$ for the WAP-eligible population.

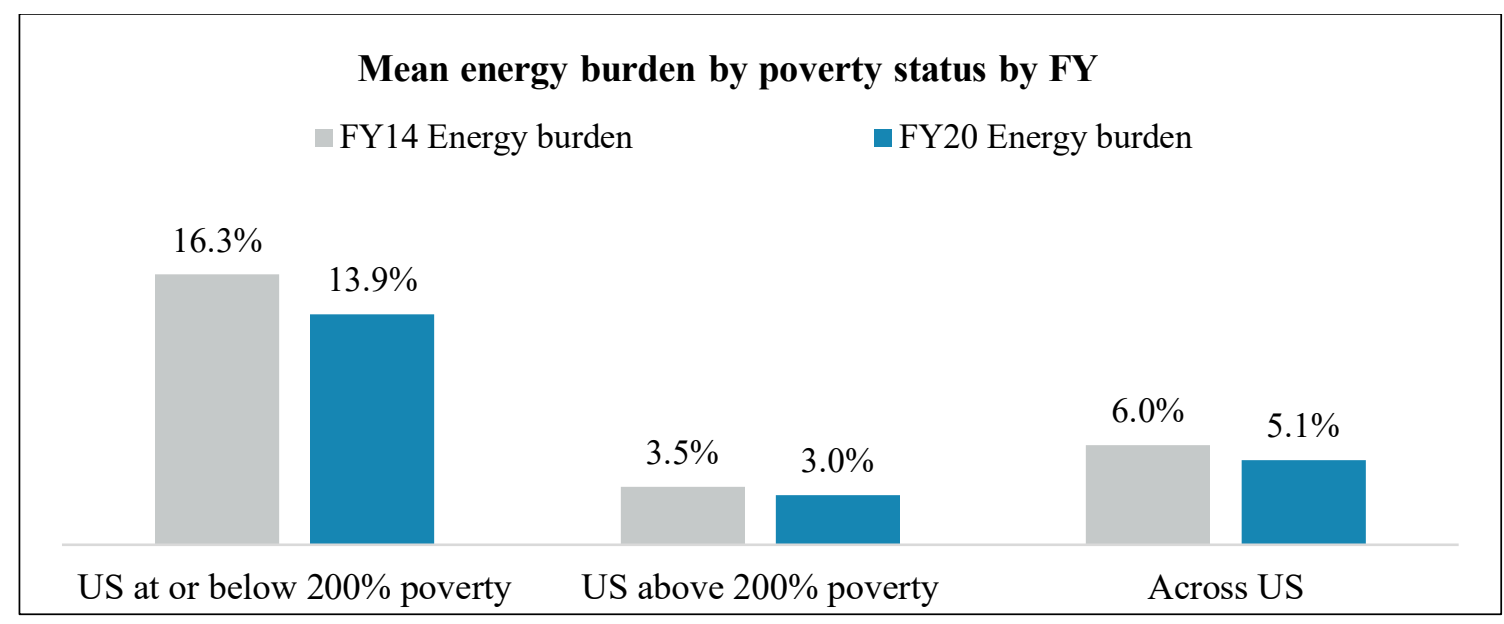

Figure 12. Mean energy burden by poverty status.

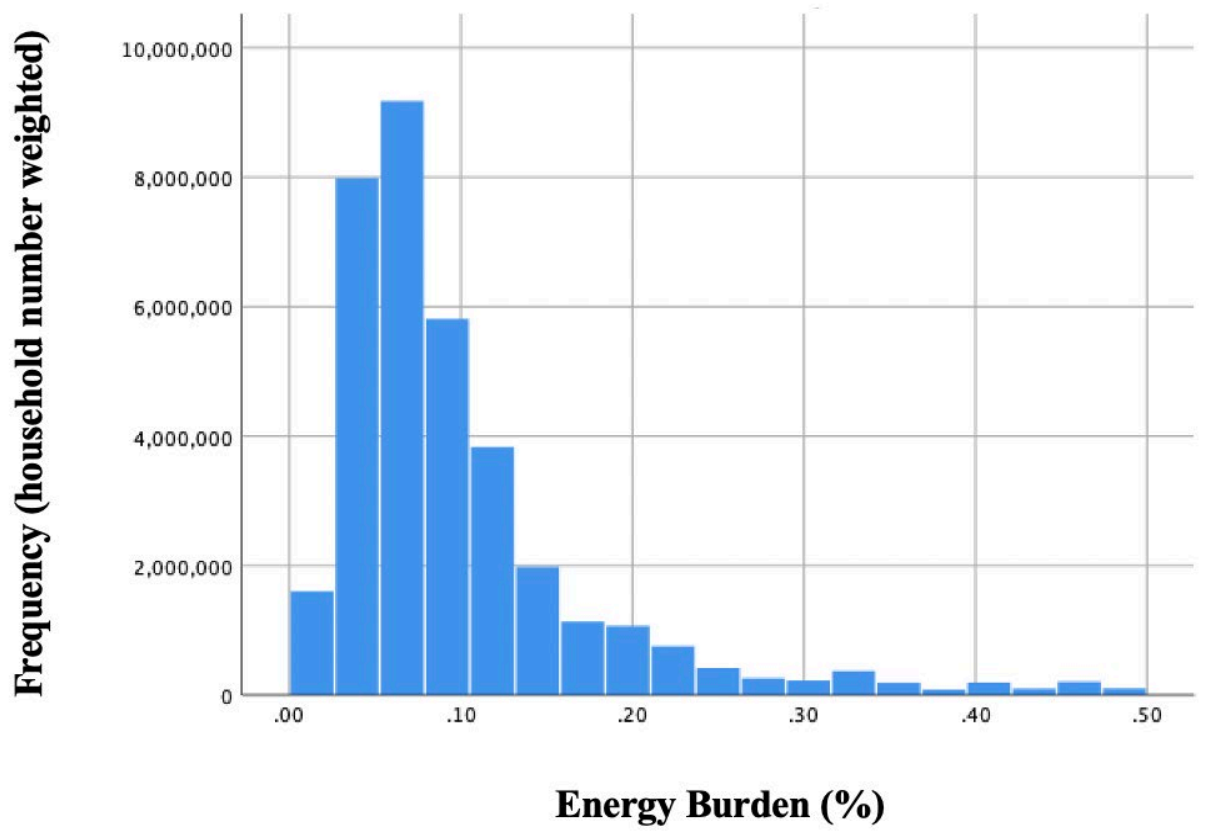

Figure 13. Distribution of annual energy expenditures for the WAP-eligible population. ${ }^{28}$

${ }^{28}$ The frequency in households uses population-weighted data for each census division (see Appendix A). 
Mean energy burden was further stratified by poverty status to calculate the burden on households at or below $100 \%$ poverty guidelines. Households living below this federal poverty line in FY 2020 are expected to spend an estimated $30.9 \%$ of their household income on home energy expenditures compared to $5.1 \%$ across the United States (Figure 14).

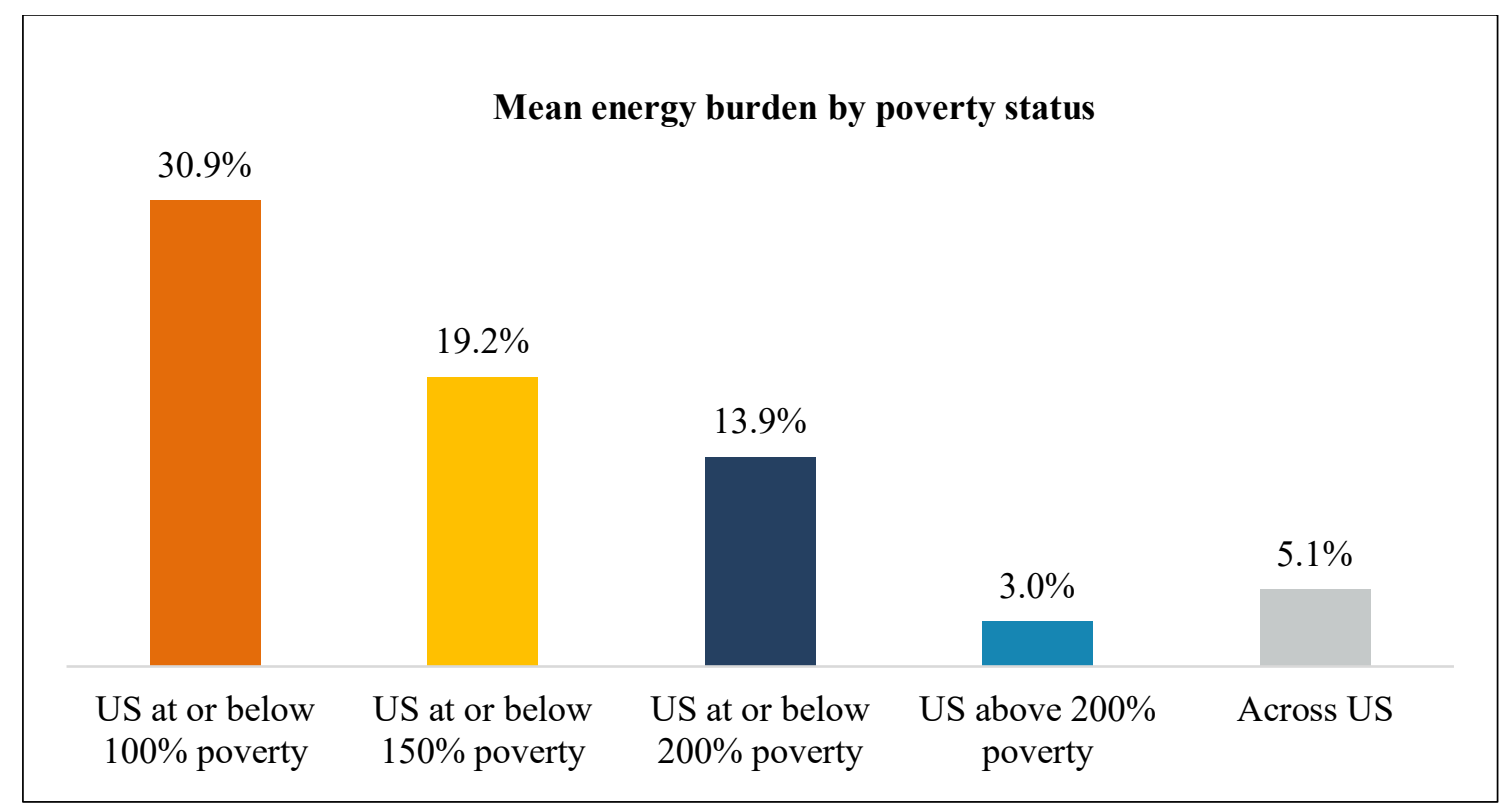

Figure 14. Energy burden for FY 2020 by poverty status.

For FY 2020, the estimated mean energy burden varied across census regions and divisions, as well as climate regions (Figures 15-17). Energy burden also varied by primary heating fuel (Figure 18) and housing type (Figure 19). WAP-eligible households heating with fuel oil experienced the highest energy burden at $22.0 \%$. On average, households living in the Northeast, Midwest and South regions of the United States are projected to spend between $14.5 \%$ and $17.3 \%$ of their income on home energy costs, compared to $8.5 \%$ in the West. Upon analyzing energy burdens in the nine census divisions, households in the South Atlantic, East South Central, New England, East North Central, and the Middle Atlantic divisions are estimated to have above-average energy burdens (between 15.3\% and 17.8\%) compared to WAP-eligible households in general (13.9\%). Households living in these divisions largely reside in the mixed-humid and cold/very cold climate zones projected to have the highest energy burden across US climate zones at $16.7 \%$ and $14.7 \%$, respectively. The lowest energy burdens for WAP-eligible households are found in the West region of the United States and in the hot-dry/mixed-dry climate region (both at $8.5 \%$ ), and the marine climate zone (also in the West region of the United States) at $9.4 \%$. 


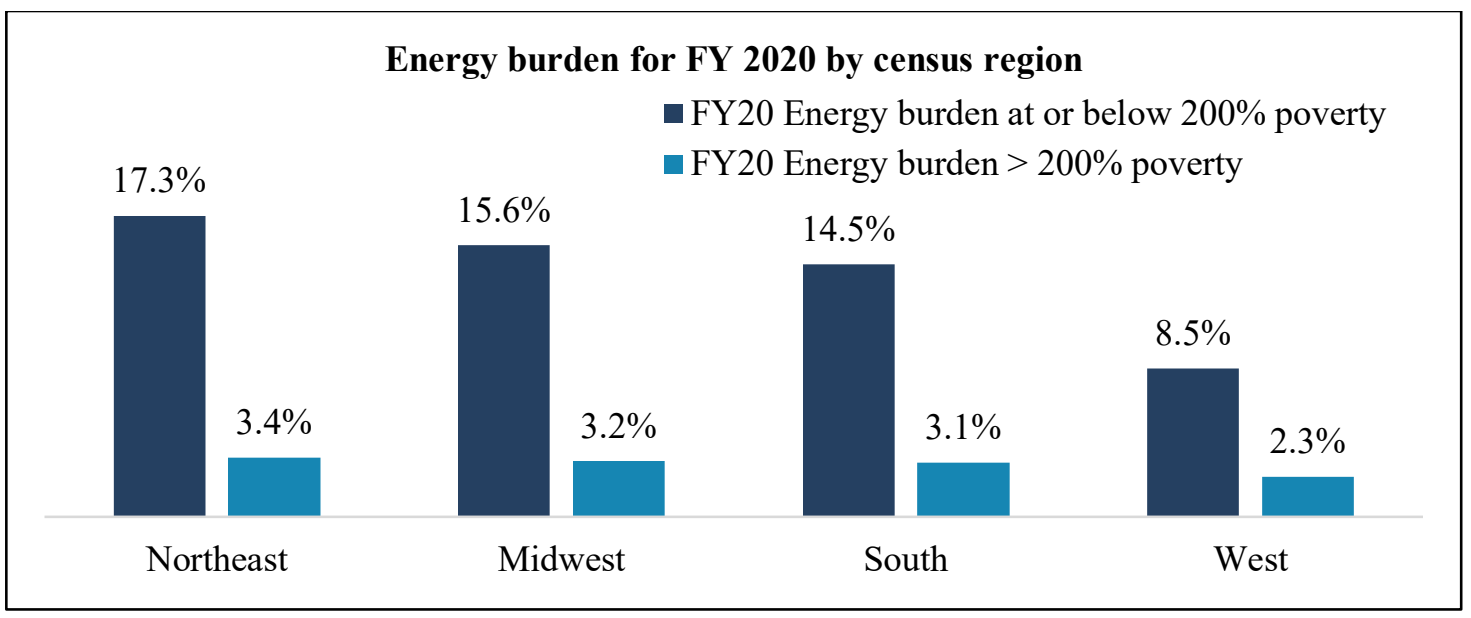

Figure 15. Energy burden for FY 2020 by census region.

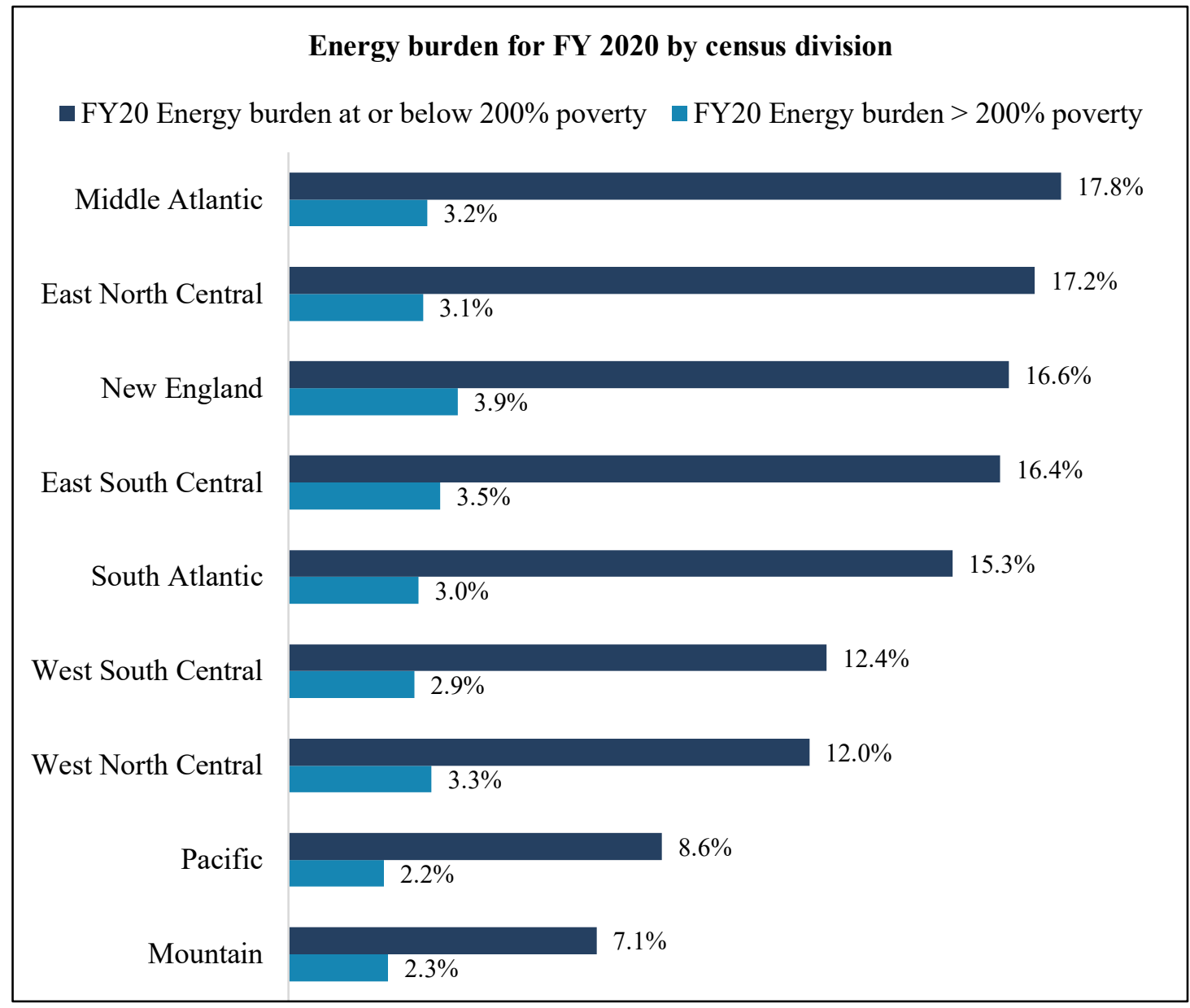

Figure 16. Energy burden for FY 2020 by census division. 


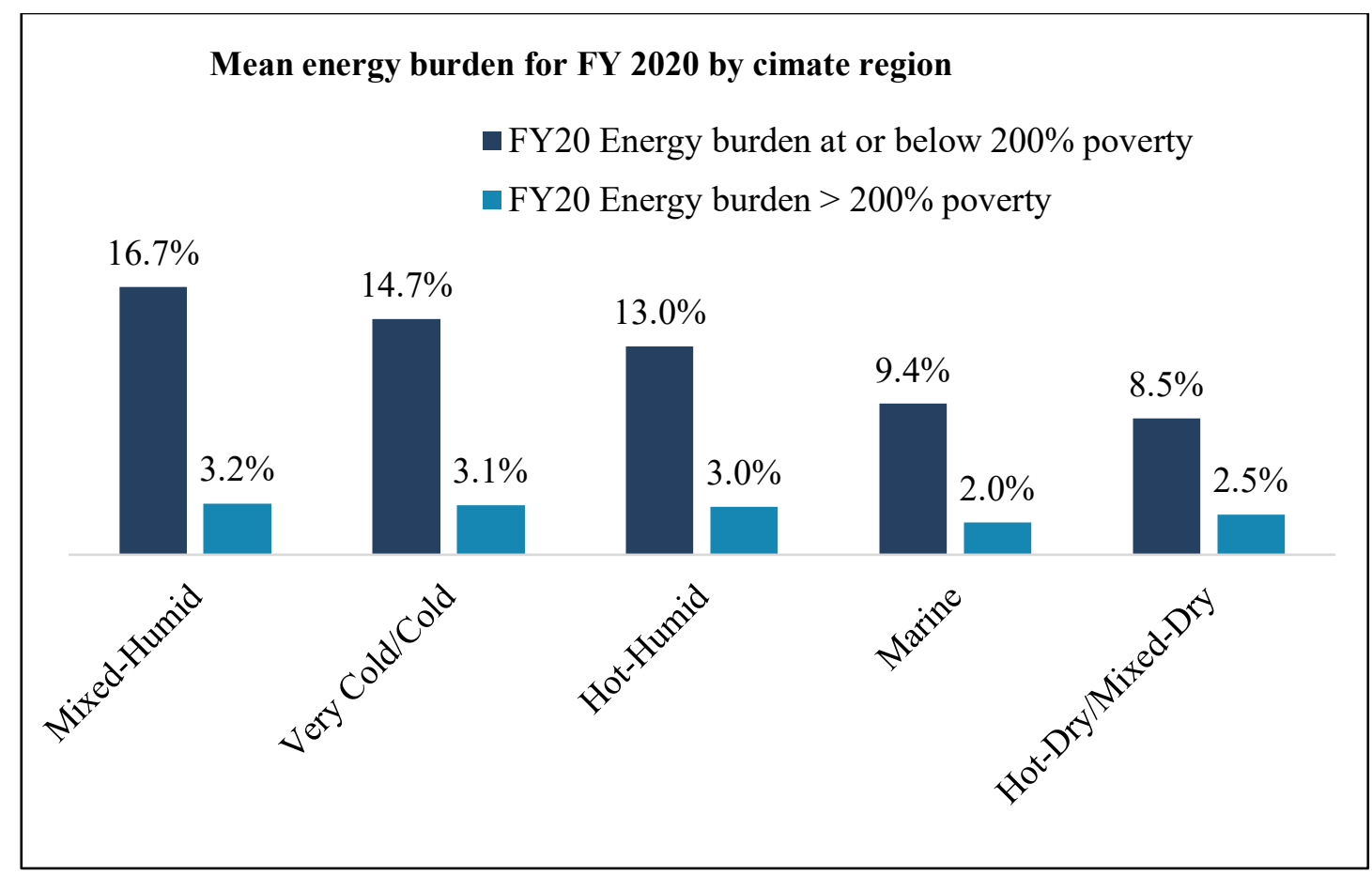

Figure 17. Mean energy burden for FY 2020 by climate region.

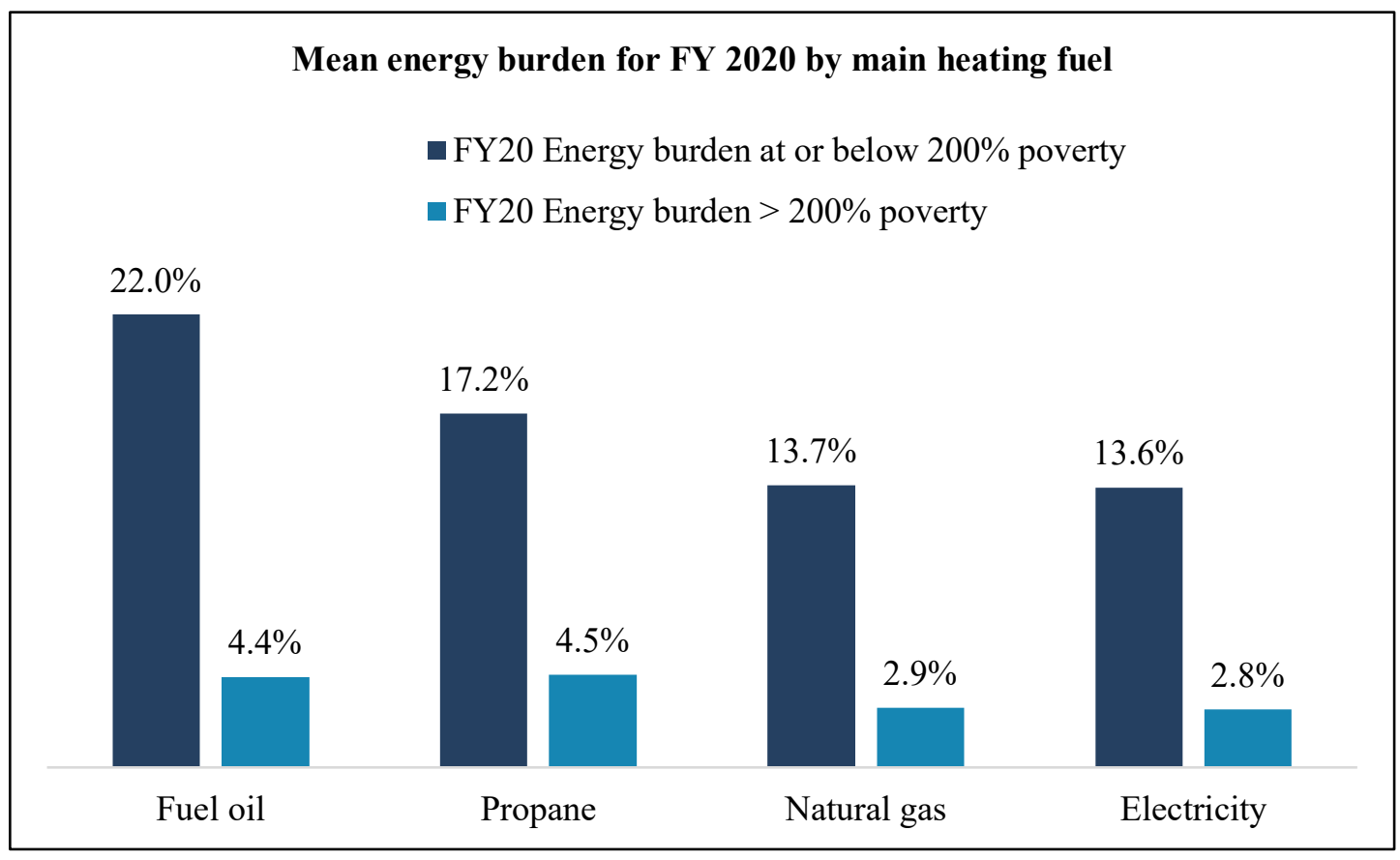

Figure 18. Mean energy burden for FY 2020 by main heating fuel 
WAP-eligible households living in large multifamily buildings are observed to have the lowest energy burden at 12.6\% (Figure 19). Despite reporting lower incomes than households in other types of housing, the average annual consumption is the lowest for households in large multifamily buildings (Section 3.1). WAP-eligible households living in small multifamily buildings and manufactured homes experience the highest energy burden for the WAP-eligible population (17.6\% and 15.4\%), and across the United States $(8.7 \%$ and $8.9 \%)$.

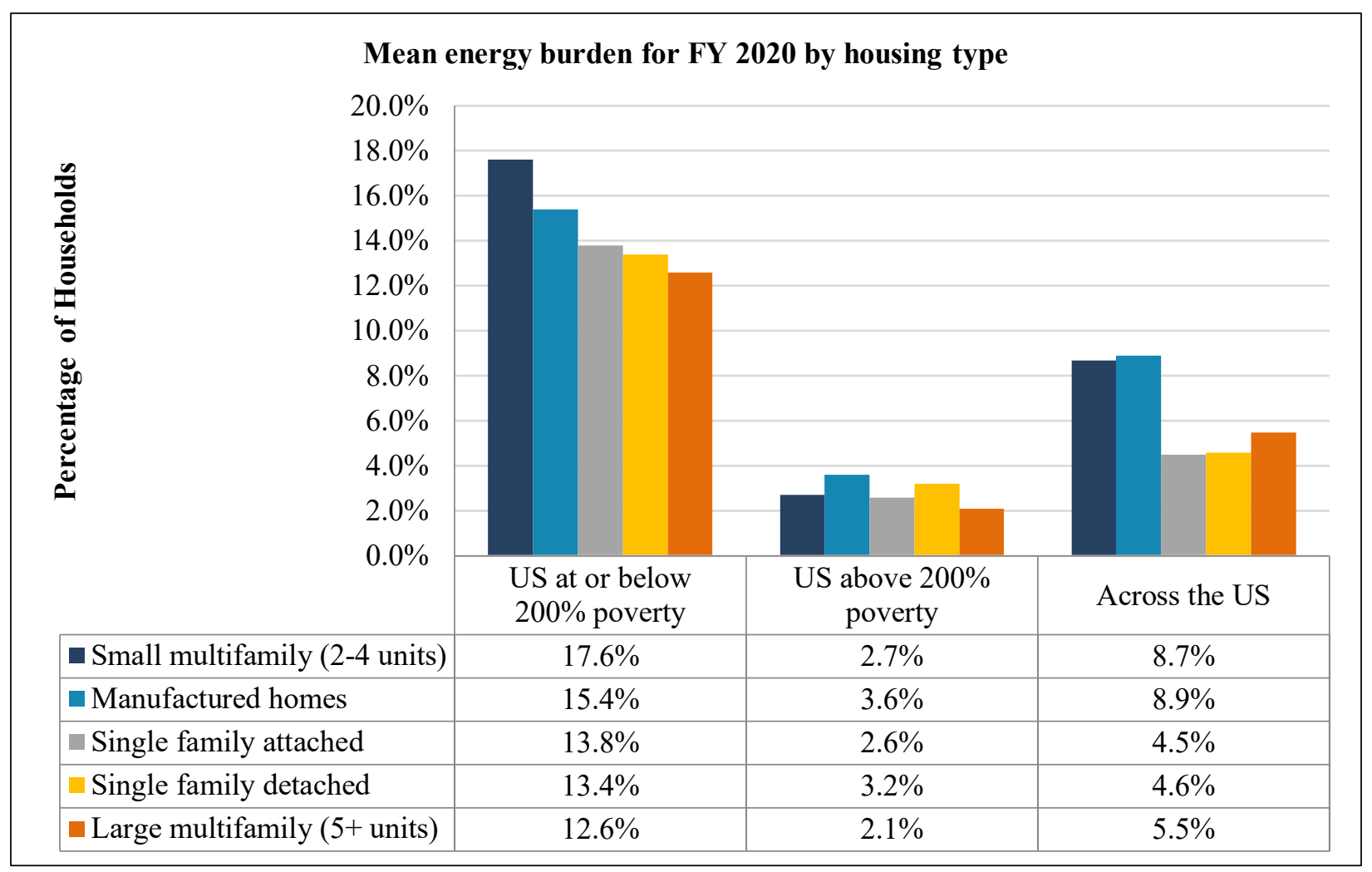

Figure 19. Mean energy burden for FY 2020 by housing type. 


\section{OTHER KEY CONSIDERATIONS FROM THE WAP EVALUATIONS}

To date, WAP has not directly measured household energy burdens or changes in household energy burden as a direct impact of the program nationally. However, energy savings were measured under the national WAP evaluations. Energy savings experienced by WAP households provide insight into the potential reduction in energy burdens estimated for the WAP-eligible population. For example, the national evaluations report energy savings higher in homes heated by fuel oil (e.g., 19.5\% savings for single-family site-built homes) and propane, which are higher priced heating fuels per MMBtu than other fuel types, and which are associated with the highest energy burdens for WAP-eligible households (Figure 15) (Carroll et al. 2014b). Across all fuel types, energy cost savings were 12.4\% on average for site-built single-family homes, or about $\$ 283$ per year (Blasnik et al. 2014). Households using natural gas as the primary heat source in small multifamily buildings (i.e., 2-4 units) benefitted from almost the same percentage of net gas savings as single-family site-built homes $(17.8 \%)$, whereas occupants of manufactured homes and large multifamily buildings saw much less savings at $12.6 \%$ and $12.4 \%$, respectively (Carroll et al. 2014b). Finally, savings in single-family homes heated by natural gas ranged from $19.6 \%$ in the hot/humid climate zone to $16.1 \%$ in the moderate climate zone (Blasnik et al. 2014). As for variation between climate zones in single-family homes heated by electricity, it was observed that homes in warmer areas appeared to achieve higher savings (14.8\%) compared to homes in colder climates (7.1\%) (Blasnik et al. 2014).

Results from the national evaluation's occupant survey indicate that WAP recipients experience a reduction in negative impacts associated with high energy burden after weatherization (Table 1) (Tonn et al. 2015). Fewer households reported finding it hard or very hard to pay energy bills one year after weatherization: $74.2 \%$ before weatherization compared to $58.5 \%$ after. Before weatherization, $33.2 \%$ of respondents reported not buying food in order to pay energy bills, and $27.5 \%$ of respondents reported they had to forego necessary prescriptions. These frequencies decreased by $10.1 \%$ and $9.0 \%$, respectively, following weatherization. In addition, the need for food assistance dropped by $6 \%$ after weatherization, and households reported an increased ability to purchase food and prescription medications. It should be noted that even after weatherization, many households continued to report experiences indicative of energy burden (Tonn et al. 2014; Tonn et al. 2015).

Table 1. Occupant survey findings: reduced energy burden after weatherization

\begin{tabular}{lccc}
\hline \multicolumn{1}{c}{$\begin{array}{c}\text { Survey } \\
\text { item }\end{array}$} & $\begin{array}{c}\text { Pre-weatherization } \\
\text { incidence }\end{array}$ & $\begin{array}{c}\text { Post- } \\
\text { weatherization } \\
\text { incidence }\end{array}$ & Difference \\
\hline Household experiences and trade offs & & & \\
\hline It is hard or very hard to pay energy bills & $74.6 \%$ & $58.5 \%$ & $-16.1 \%$ \\
Did not buy food to pay energy bills & $33.2 \%$ & $23.1 \%$ & $-10.1 \%$ \\
Did not fill prescriptions to pay energy bills & $27.5 \%$ & $18.5 \%$ & $-9.0 \%$ \\
Went without food in the last four weeks & $7.1 \%$ & $5.7 \%$ & $-1.4 \%$ \\
Received food stamps or Women, Infants, and & $56 \%$ & $50 \%$ & $-6 \%$ \\
Children (WIC) assistance in the past year & & & \\
\hline
\end{tabular}




\section{CONCLUSIONS AND RECOMMENDATIONS}

The primary conclusion derived from this study is that WAP continues to serve a population with an energy burden that is much greater than the rest of the county. Based on an analysis of the 2009 RECS that accounts for changes in fuel prices and inflationary adjustments in income, the energy burden for the WAP-eligible population was estimated to be $13.9 \%$ for FY 2020 compared to $3.0 \%$ for the remaining US population.

The energy burden for the WAP-eligible population has remained steady at this high level regardless of how fuel prices have changed over the last decade. The energy burden for the WAP-eligible population for FY 2010 and FY 2014 was previously estimated to be $14.2 \%$ and $16.3 \%$, respectively.

Although slightly different characteristics were observed between the WAP-eligible population and clients actually served by WAP, the energy burden estimated for the WAP-eligible population should be representative of households weatherized by WAP. Observations included some differences in household income, housing characteristics, and primary fuel types used for space heating.

A final conclusion derived from this study is that WAP clients with energy burdens that are higher than average could be targeted by focusing on eligible households or houses with select characteristics. On average, the energy burden of households with incomes at or below $100 \%$ or $150 \%$ of poverty are higher than the general WAP-eligible population ( $200 \%$ of poverty): $30.9 \%$ or $19.2 \%$, respectively, compared to $13.9 \%$. Homes heated primarily by fuel oil or propane have on average higher burdens than those heated by natural gas or electricity ( $22 \%$ and $17.2 \%$ compared to $13.7 \%$ and $13.6 \%$, respectively). To a lesser extent, small multifamily housing units and manufactured homes exhibit higher energy burdens than average (17.6\% and $15.4 \%$, respectively). There are regional differences in the energy burden of the population served by WAP due to regional differences in fuel types, housing types, and climate.

It is recommended that the analysis presented in this report be updated in FY 2021 when the 2020 RECS data become available. It is anticipated that the 2020 RECS will use narrow income bands as used in the 2009 RECS rather than the wide bands used in the 2015 RECS that prevented the use of the 2015 RECS in this analysis. The 2020 RECS will provide current utility bills and incomes for the WAP-eligible population that will not require significant if any adjustments as required in using the 2010 RECS for this analysis.

It is also recommended that energy burdens calculated for the WAP-eligible population from this or future analyses be compared to energy burden data for clients actually served by the program if and when such data are collected and become available. Such analysis will help identify differences between the WAP-eligible population and the population actually served by the program and if changes are desired in how clients are selected or marketed. 


\section{REFERENCES}

Blasnik, M., G. Dalhoff, S. Pigg, A. Mendyk, D. Carroll, F. Ucar, 2014. National Weatherization Assistance Program Impact Evaluation: Energy Impacts for Single Family Homes. ORNL/TM2015/13, Oak Ridge National Laboratory, Oak Ridge, Tennessee.

Blasnik, M., G. Dalhoff, D. Carroll, F. Ucar, and. Bausch, 2015. Evaluation of the National Weatherization Assistance Program During Program Years 2009-2011 (American Recovery and Reinvestment Act Period): Energy Impacts for Single Family Homes. ORNL/TM-2014/582, Oak Ridge National Laboratory, Oak Ridge, Tennessee.

Carroll, D., J. Berger, C. Miller, C. Driscoll, 2014a. National Weatherization Assistance Program Impact Evaluation - Baseline Occupant Survey: Assessment of Client Status and Needs. ORNL/TM-2015/22. Oak Ridge National Laboratory. Oak Ridge, Tennessee.

Carroll, D., M. Blasnik, G. Dalhoff, 2014b. National Weatherization Assistance Program Impact Evaluation: Impact Summary Report. ORNL/TM-2014/437, Oak Ridge National Laboratory, Oak Ridge, Tennessee.

Carroll, D., G. Dalhoff, D. Johnson, D. Bausch, M. Blasnik, 2015. Energy Impacts for Multifamily Buildings: Evaluation of the National Weatherization Assistance Program During Program Years 2009-2011 (American Recovery and Reinvestment Act Period). ORNL/TM-2014/583, Oak Ridge National Laboratory, Oak Ridge, Tennessee.

Eisenberg, J., 2010. Weatherization Assistance Program Technical Memorandum Background Data and Statistics, ORNL/TM-2010/66, Oak Ridge National Laboratory, Oak Ridge, Tennessee.

Eisenberg, J., 2014. Weatherization Assistance Program Technical Memorandum Background Data and Statistics on Low-Income Energy Use and Burdens ORNL/TM-2014/133, Oak Ridge National Laboratory, Oak Ridge, Tennessee.

Energy Information Administration, 2009, Annual Energy Outlook for 2010, Early Release, Washington, DC.

Energy Information Administration, 2019, Short-Term Energy Outlook, October 2019, Washington, DC.

Tonn, B. et al., 2014. Weatherization Works - Summary of Findings from the Retrospective Evaluation of the US Department of Energy's Weatherization Assistance Program. ORNL/TM-2014/338. Oak Ridge National Laboratory. Oak Ridge, Tennessee.

Tonn, B., E. Rose, B. Hawkins, 2015. Survey of Recipients of Weatherization Assistance Program Services: Assessment of Household Budget and Energy Behavior Pre- to Post-Weatherization. ORNL/TM-2015/64, Oak Ridge National Laboratory, Oak Ridge, Tennessee.

US Census Bureau, 2012, Income, Poverty, and Health Insurance Coverage in the United States, Washington, DC.

US Department of Commerce, National Oceanic and Atmospheric Administration, 2007. Historical Climatology Series 5-1, Monthly, State, Regional, and National Heating Degree Days, Asheville, North Carolina.

US Department of Health and Human Services, 2014. 2014 Poverty Guidelines, available at http://aspe.hhs.gov/poverty/14poverty.cfm (accessed April 22, 2020).

US National Weather Service, Climate Prediction Center, 2007. Experimental Monthly Total Degree Day Forecast, Camp Springs, Maryland 


\section{APPENDIX A. METHODOLOGY}

The method used to estimate energy expenditures and hence energy burdens for WAP-eligible households was adapted from the original approach developed and described below by Joel Eisenberg (2010).

The 2009 RECS public use files identify the location of each household by census region and census division (Figure 3) and by climate regions (Figure 9). Heating and cooling degree days are provided for each household based on the population-weighted data for each census division. Income is provided for each household in 24 categories. The survey also provides actual fuel bills for each household and uses statistical techniques to allocate the usage and expenditures among major usage categories such as heating, cooling, hot water heating, and refrigeration.

Long-range climate normals for heating and cooling degree days for each census division were calculated using statistics provided by the National Climatic Data Center of the National Oceanic and Atmospheric Administration, National Environmental Satellite, Data and Information Service. These data were used to calculate an adjustment factor for each census division so that the RECS data on heating and cooling expenditures for 2009 could be adjusted to reflect normal weather conditions.

Annual price adjustment factors were calculated using quarterly price projections by census division for natural gas and electricity and by census region for propane and heating oil as provided by the STEO each fall. The quarterly prices were weighted by consumption for each quarter to calculate an annual price adjustment factor for the historical record for 2009 and for the price projections for each year thereafter through FY 2020. The baseline 2009 energy prices used to calculate multipliers were derived from the historical STEO database. This methodology provides a conservative and internally consistent approach to the estimation problem.

The estimate of an individual household's expenditure for a given year $n$ was then calculated using the following formula in the Statistical Package for the Social Sciences (SPSS):

$((($ Dolngsph $*$ hddfact $)+$ Dolngwth + Dolngoth $) *$ pmngY $)+((($ Dolpsph $*$ hddfact $)+$ Dollpwth

+ Dollpoth $)^{*}$ pmlp Y $)+((($ Dolkrsph*hddfact $)+$ Dolkrwth+Doldroth $) *$ pmfoY $)+$

$((($ Dolfosph*hddfact $)+$ Dolfowth + Dolfooth $) *$ pmfoY $)+((($ Dolelsph * hddfact $)+($ Dolelcol $*$

cddfact) + doleloth + dolelrfg + dolelwth)* pmelY) where:

'Dol' signifies the expenditure for 2009,

'ng' represents natural gas

' $\mathrm{p}$ ' represents propane

'kr' represents kerosene

'fo' represents fuel oil

'el' represents electricity

'hddfact' is the heating degree day adjustment factor for normalization

'cddfact' is the cooling degree day adjustment factor for normalization

'sph' is space heating

'wth' is water heating

'oth' is other appliances and uses

'col' is cooling,

'rfg' is refrigerator

' $\mathrm{pm}$ ' is price multiplier

' $\mathrm{Y}$ ' is the fiscal year 
Regional estimates were then made using the sort functions of SPSS to select households by region and qualification of eligibility, and the Explore statistical function was used to derive means, medians, and standard deviations by primary heating fuel type for total expenditures, as well as heating and cooling expenditures for each year. Statistics were generated on a weather normalized projected basis for FY 2009 through FY 2020.

To estimate 2020 income for the WAP-eligible population, data from the 2009 RECS was adjusted using inflation multipliers derived from the US Bureau of Labor Statistics Consumer Price Index (CPI) by census region. Then a money multiplier was created in SPSS for each census region. Point estimates of household income in 2020 were then calculated for each of the 24 income brackets using the money multiplier. New variables for FY 2020 poverty status $(<100 \%,<150 \%,<200 \%$, and $200 \%+)$ were recoded: 'pov100', 'pov150', and 'pov200'. 